Supporting information for

\title{
Target-Activated Modulation of Dual-Color and Two-Photon Fluorescence of Graphene Quantum Dots for in Vivo Imaging of Hydrogen Peroxide
}

Wenjie Zhao, ${ }^{\dagger, \S}$ Yinhui Li, ${ }^{\dagger} \S$ Sheng Yang, ${ }^{\ddagger} *$ Yun Chen,${ }^{\dagger}$ Jing Zheng, ${ }^{\dagger}$ Changhui Liu, ${ }^{\dagger}$ Zhihe Qing, ${ }^{\dagger}$ Jishan $\mathrm{Li}^{\dagger}{ }^{\dagger}$ and Ronghua Yang ${ }^{\dagger, \star * *}$

${ }^{\dagger}$ State Key Laboratory of Chemo/Biosensing and Chemometrics, College of Chemistry and Chemical Engineering, and Collaborative Innovation Center for Chemistry and Molecular Medicine, Hunan University, Changsha, 410082, P. R. China; ${ }^{\ddagger}$ School of Chemistry and Biological Engineering, Changsha University of Science and Technology, Changsha 410004, P. R. China.

\author{
${ }^{\S}$ These authors contributed equally. \\ *To whom correspondence should be addressed: \\ E-mail: Yangrh@pku.edu.cn; ysh1127@hnu.edu.cn
}

Fax: +86-731-8882 2523 


\section{Contents}

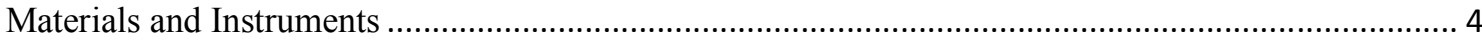

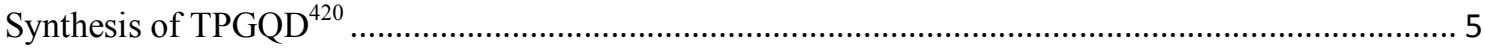

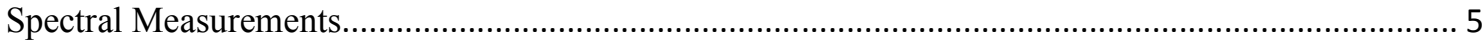

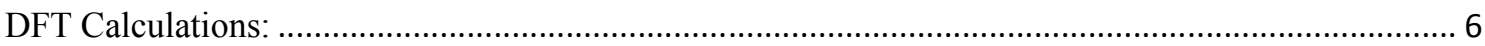

Measurements of One-photon Quantum Yields and Two-Photon Absorbance Cross Section ............... 6

Cell Incubation and Cytotoxicity Assay ...................................................................................... 7

Mice Culture and Preparation of Tumor Tissue Slices .................................................................. 8

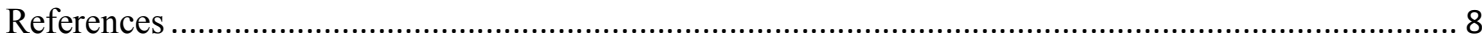

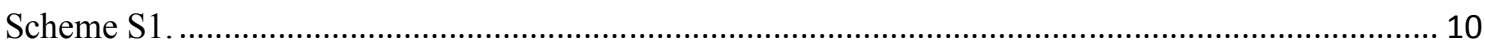

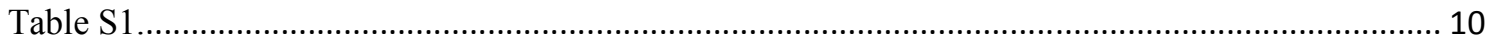

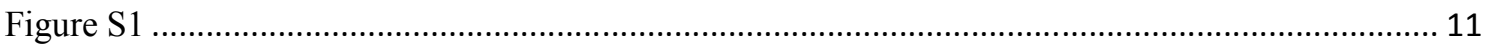

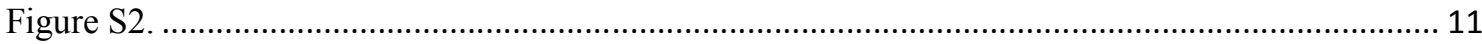

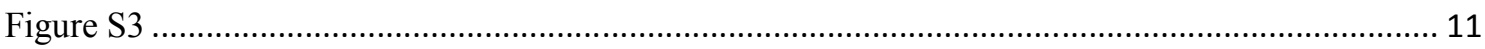

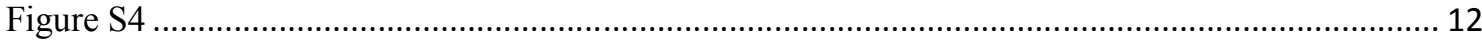

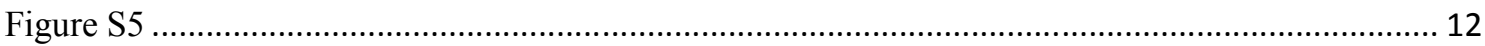

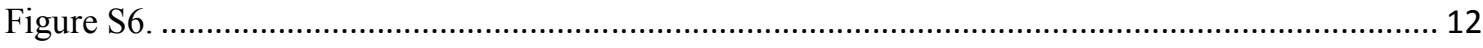

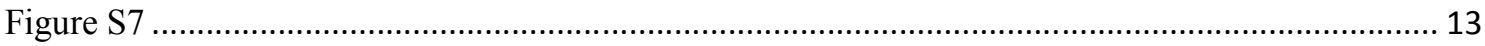

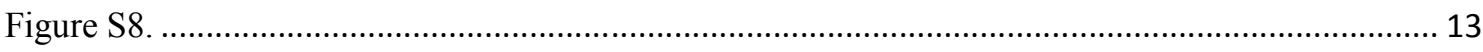

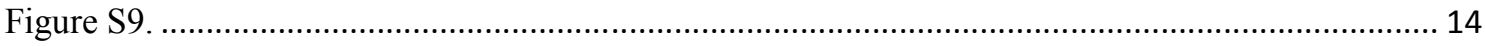

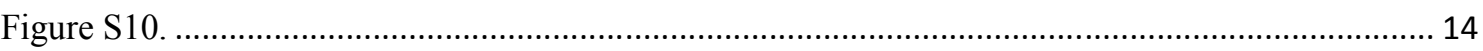

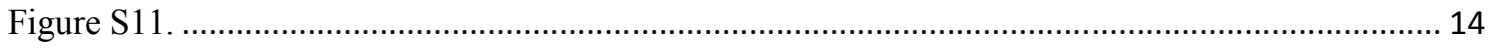

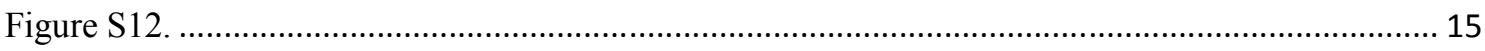

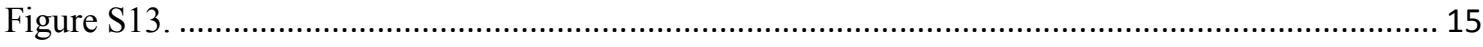

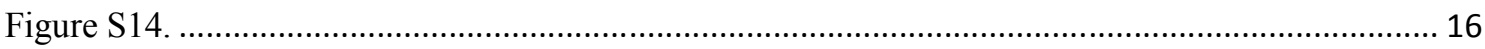

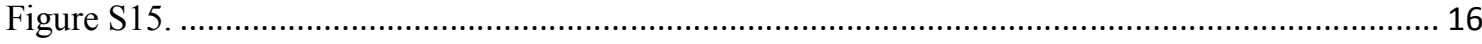

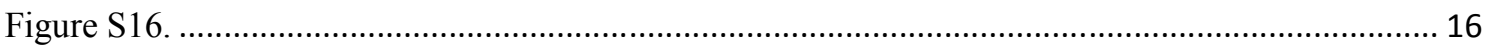

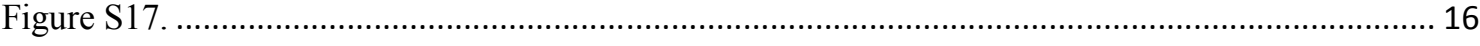

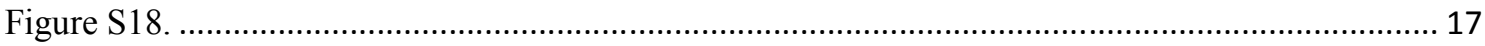

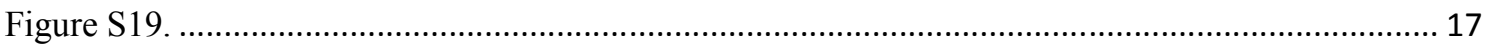




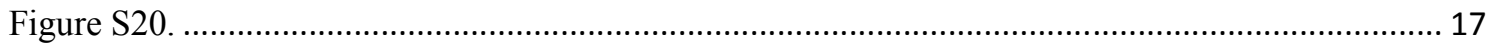

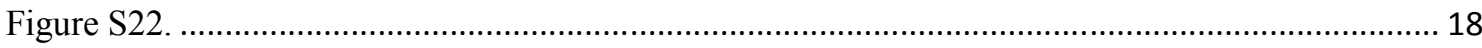

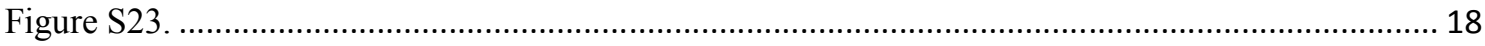

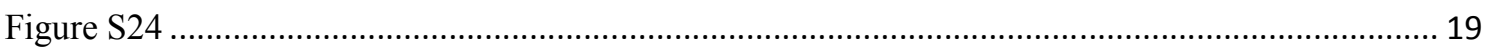

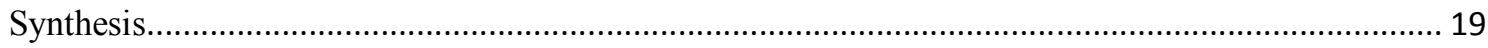

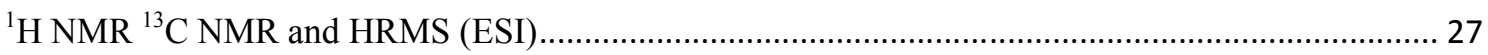




\section{Materials and Instruments}

All the chemical reagents were purchased from Alfa Aesar. The reactive oxygen species (ROS) were prepared following reported literature. ${ }^{1}$ The graphene oxide (GO) used in this work was purchased from XFNANO Materials Tech Co., Ltd. (China). Working solutions were prepared by successive dilution of the stock solution with PBS buffer $(20 \mathrm{mM}, 10 \%$ DMF, pH 7.4).

UV-Vis absorption spectra were recorded using a Hitachi U-4100 UV/Vis spectrophotometer (Kyoto, Japan) in $1 \mathrm{~cm}$ path length quartz cuvettes. The steady-state fluorescence emission spectra were obtained from a was measured on a Photon Technology Intl. Fluorescence emission spectra were collected using a bandwidth of $5 \mathrm{~nm}$ and $0.5 \times 1 \mathrm{~cm}^{2}$ quartz cuvettes containing $500 \mu \mathrm{L}$ of solution. AFM images were obtained using a Nanoscope IIIa apparatus (Digital Instruments, USA) equipped with a J Scanner. Transmission electron microscopy (TEM) images were obtained on an H-7000 NAR transmission electron microscope (Hitachi) with a working voltage of $100 \mathrm{kV} .{ }^{1} \mathrm{H}$ and ${ }^{13} \mathrm{C}$ NMR spectra were recorded on an Invoa-400 (Invoa 400) spectrometer and referenced to solvent signals. Mass spectra were measured on LCQ/Advantage HPLC-Mass spectrotometer. X-ray photoelectron spectroscopy (XPS) (model K-Alpha 1063, Thermo Fisher Scientific, UK) equipped with Al $\mathrm{K}$ source (1486.6 $\mathrm{eV}$ photons) was used to track the assembly process of the probe. All binding energies (BEs) were referred to as the $\mathrm{C} 1 \mathrm{~s}$ peak $(284.6 \mathrm{eV})$ arising from surface hydrocarbons. The fluorescence images were acquired from the blue channel (400-450 nm) and green channel $(500-550 \mathrm{~nm})$ upon two-photon excitation at $740 \mathrm{~nm}$ with a pulse laser by using an Olympus FV1000 laser confocal microscope. 


\section{Synthesis of TPGQD ${ }^{420}$}

In brief the graphene oxide (GO) was dissolved in dimethylformamide (DMF) with a concentration of $\sim 200 \mathrm{mg} \mathrm{mL}^{-1}$. The GO and DMF mixed solution was ultrasonicated for 30 minutes $(120 \mathrm{~W}, 100 \mathrm{kHz})$ and then transferred to a poly(tetrafluoroethylene)-lined autoclave (30 mL) and heated at $200 \square$ for $5 \mathrm{~h}$. After cooling to room temperature naturally, the obtained mixture was filtered through a $0.22 \mu \mathrm{m}$ microporous membrane to remove the black precipitates, obtaining a brown solution. The solvent was removed with the aid of a rotary evaporator. Then obtained TPGQD ${ }^{420}$ was dispersed in DI water. The product dialyzed through a $3.5 \mathrm{KDa}$ dialyzer for at least 48 hours. Then obtained pure TPGQD ${ }^{420}$ used for further characterization.

\section{Spectral Measurements}

The BMC1-4, BMC3-COOH, and TPGQD ${ }^{420}-\mathrm{BMC}$ were used to prepare stock solutions in Millipore water. Test solutions were prepared by placing TPGQD ${ }^{420}-\mathrm{BMC} 3$ an appropriate aliquot of each analyte stock into a flask and then diluting the solution to a volume of $500 \mathrm{~mL}$ with 20mM PBS, pH 7.4 (containing $10 \%$ DMF). The resulting solution was kept at ambient temperature for $30 \mathrm{~min}$, and then the fluorescence intensities were recorded with two-photon excitation at $740 \mathrm{~nm}$. In kinetic studies, the apparent rate constant $k$ for the reaction of BMC1-4 with $\mathrm{H}_{2} \mathrm{O}_{2}$ were determined by fitting the absorbance intensities to the pseudo first-order:

$$
\ln \left[\left|\left(\mathrm{A}_{\max }-\mathrm{A}_{\mathrm{t}}\right)\right| / \mathrm{A}_{\max }\right]=-k \mathrm{t}^{2}
$$

Where $A_{t}$ and $A_{\max }$ are the absorbance intensities of BMC1-4 at a time $t$ and the maximum value obtained after the reaction was complete.

The observed rate constant $k^{\prime}$, contains the concentration of $\mathrm{H}_{2} \mathrm{O}_{2}$ as a constant and is 
related to the second-order rate constant, $k\left(\mathrm{M}^{-1} \mathrm{~s}^{-1}\right)$, by equation:

$$
k^{\prime}=k\left[\mathrm{H}_{2} \mathrm{O}_{2}\right]
$$

\section{DFT Calculations: ${ }^{3}$}

The ground state structures of dyes BMC1-4 were optimized using DFT with B3LYP functional and $6-31+\mathrm{G}(\mathrm{d}, \mathrm{p})$ basis set. The initial geometries of the compounds were generated by the Gauss View software. All of these calculations were performed with Gaussian 09 (Revision A.02).

\section{Measurements of One-photon Quantum Yields and Two-Photon Absorbance Cross Section}

The one-photon quantum yields (QY) of samples were estimated using Rhodamine B or quinine sulfate as a reference standard, which was freshly prepared to reduce the measurement error. ${ }^{4}$ The quantum yield $\boldsymbol{\Phi}$ as a function solvent polarity is calculated using the following equation:

$$
\Phi_{F}=\Phi_{F, \mathrm{cal}} \cdot \frac{S}{S_{c a l}} \cdot \frac{A_{c a l}}{A} \cdot \frac{n^{2}}{n_{c a l}^{2}}
$$

Where $\boldsymbol{\Phi}_{\mathrm{F}}$ is the quantum yield, $\boldsymbol{S}$ is the areas' integral values of the corrected fluorescence spectra, $\boldsymbol{A}$ stands for the absorbance and $\boldsymbol{n}$ is refractive index. The subscript cal and no denote the standard and sample, respectively.

The two-photon absorption (TPA) cross sections $(\boldsymbol{\delta})$ of samples (in the wavelength range of 690-860 nm) in neutral conditions were determined using TPE method with femtosecond Ti-sapphire laser pulses described in previous literature. ${ }^{5} \mathrm{TPGQD}^{420}(1.46 \mu \mathrm{g} / \mathrm{mL})$ or BMC 1-4 (10 $\mu \mathrm{M})$ was dissolved in PBS buffer ( $\mathrm{pH} 7.4)$, and the TPE fluorescence emission intensity was measured in the emission range 380-450 $\mathrm{nm}$ under excitation at $690-860$ 
nmusing Rhodamine B as the reference, whose TP properties have been well-characterized in the previous literature. ${ }^{6}$ Intensities of TPE fluorescence emission of the reference and the samples emitted at the same excitation wavelength were determined. The TPA cross section was calculated as the following equation: ${ }^{7,8}$

$$
\delta_{S}=\frac{S_{S}}{S_{R}} \cdot\left[\frac{\Phi_{R} \cdot C_{R} \cdot n_{S}}{\Phi_{S} \cdot C_{S} \cdot n_{R}}\right] \delta_{R}
$$

Subscript $\boldsymbol{S}$ and $\boldsymbol{R}$ denote the sample and the reference, respectively. $\boldsymbol{S}$ represents the intensity of TPE fluorescence emission, $\boldsymbol{\Phi}$ is the fluorescence quantum yield, $\boldsymbol{C}$ denotes the concentration, and $\boldsymbol{n}$ represents the refractive index of the solvents.

\section{Cell Incubation and Cytotoxicity Assay}

HeLa cells were obtained from the biomedical engineering center of Hunan University (Changsha, China). Those cell was cultured using high-glucose Dulbecco's modified Eagle's medium (DMEM, GIBCO) with $1 \%$ penicillin-streptomycin $\left(10,000 \mathrm{U} / \mathrm{mL}, 10,000 \mu \mathrm{g} \mathrm{mL}^{-1}\right.$, Invitrogen) and $10 \%$ fatal bovine serum (GIBCO) in an atmosphere of $5 \% \mathrm{CO}_{2}$ and $95 \%$ air at $37^{\circ} \mathrm{C}$.

The cellular cytotoxicity of TPGQD ${ }^{420}$-BMC3@PEG towards HeLa cells as the model was evaluated using the standard cell viability assay - the MTT assay. ${ }^{9}$ HeLa cells were seeded into a 96-well plate at a concentration of $5 \times 10^{3}$ cells well $^{-1}$ in $100 \mu \mathrm{L}$ of DMEM medium with $10 \%$ FBS. Plates were maintained at $37{ }^{\circ} \mathrm{C}$ in a $5 \% \mathrm{CO}_{2} 95 \%$ air incubator for $24 \mathrm{~h}$. After the original medium was removed, the HeLa cells were incubated with TPGQD ${ }^{420}$-BMC3@PEG with different concentration $\left(0,5,10,20\right.$, and $\left.50 \mu \mathrm{g} \mathrm{mL}^{-1}\right)$. The cells incubated with the culture medium only were served as the controls. The cells were washed with PBS for three 
times and then $100 \mu \mathrm{L}$ MTT solution $\left(0.5 \mathrm{mg} \mathrm{mL}^{-1}\right.$ in PBS) was added to each well. After addition of DMSO $\left(150 \mu \mathrm{L}\right.$ well $\left.{ }^{-1}\right)$, the assay plate was allowed to shake at room temperature for $10 \mathrm{~min}$. The spectrophotometrical absorbance of the samples was measured by using a Tecan microplate (ELISA) reader. The cell viability was calculated based on measuring the $\mathrm{UV}$-vis absorption at $570 \mathrm{~nm}$ using the following equation, where $\mathrm{OD}_{570}$ represents the optical density. ${ }^{10}$

$$
\text { Cell viability }=\left[\mathrm{OD}_{570(\text { (sample) }}-\mathrm{OD}_{570(\text { blank })}\right] /\left[\mathrm{OD}_{570(\text { control })}-\mathrm{OD}_{570(\text { (blank })}\right]
$$

\section{Mice Culture and Preparation of Tumor Tissue Slices}

Eight-week-old BALB/c nude mice (male) purchased from SJA Co., Ltd. (Changsha, China) were used as in vivo imaging mode and the previous procedure of cervical tumor tissue slices preparation. All animal operations were in accord with institutional animal use and care regulations, according to protocol No. SYXK (Xiang) 2008-0001, approved by Laboratory Animal Center of Hunan. Preparation of cervical tumor tissue slices follow the previous procedure: a total of $2 \times 10^{6} \mathrm{HeLa}$ cells diluted in $100 \mu \mathrm{L}$ of serum-free DMEM medium were injected subcutaneously into the right flank of 6 to 8 -week-old BALB/c nude mice to inoculate tumors. After inoculation for 15-20 days, mice were sacrificed. Tumors were transferred and embedded with O.C.T (Sakura Finetek, USA, Torrance, CA) for frozen sections. The tissues were cut into $10 \mu \mathrm{m}$ thick slices using a vibrating-blade microtome.

\section{References}

(1) Yuan, L.; Lin, W.; Zhao, S. J. Am. Chem. Soc. 2012, 134, 13510-13523.

(2) Dale, T. J.; Rebek, J. J. Am. Chem. Soc. 2006, 128, 4500-4501.

(3) Frisch, M. J.; Trucks, G. W.; Schlegel, H. B.; Scuseria, G. E.; Robb, M. A.; Cheeseman, J. 
R.; Scalmani, G.; Barone, V.; Mennucci, B.; Petersson, G. A.; Nakatsuji, H.; Caricato, M.; Li, X.; Hratchian, H. P.; Izmaylov, A. F.; Bloino, J.; Zheng, G.; Sonnenberg, J. L.; Hada, M.; Ehara, M.; Toyota, K.; Fukuda, R.; Hasegawa, J.; Ishida, M.; Nakajima, T.; Honda, Y.; Kitao, O.; Nakai, H.; Vreven, T.; Montgomery, J. A.; Peralta, J. E.; Ogliaro, F.; Bearpark, M.; Heyd, J. J.; Brothers, E.; Kudin, K. N.; Staroverov, V. N.; Kobayashi, R.; Normand, J.; Raghavachari, K.; Rendell, A.; Burant, J. C.; Iyengar, S. S.; Tomasi, J.; Cossi, M.; Rega, N.; Millam, J. M.; Klene, M.; Knox, J. E.; Cross, J. B.; Bakken, V.; Adamo, C.; Jaramillo, J.; Gomperts, R.; Stratmann, R. E.; Yazyev, O.; Austin, A. J.; Cammi, R.; Pomelli, C.; Ochterski, J. W.; Martin, R. L.; Morokuma, K.; Zakrzewski, V. G.; Voth, G. A.; Salvador, P.; Dannenberg, J. J.; Dapprich, S.; Daniels, A. D.; Farkas, O.; Foresman, J. B.; Ortiz, J. V.; Cioslowski, J.; Fox, D. J. Gaussian, Inc., Wallingford CT, GAUSSIAN 09 (Revision A.02), Gaussian, Inc., Pittsburgh, PA, 2009.

(4) Demasa, J. ; Crosby, G. A. J. Phys. Chem. 1971, 75, 991-1024.

(5) Lee, S.; Yang,W.; Choi,J.; Kim,C.; Jeon, S.; Cho,B. Org. Lett. 2005, 7, 323-326.

(6)Makarov,N.; Drobizhev, M.; Rebane,A. Opt. Express. 2008, 16, 4029-4047.

(7) Xu, C.; Webb, W. J. Opt. Soc. Am. B. 1996, 13, 481-491.

(8) Rumi, M.; Ehrlich,J.; Heikal,A.; Perry,J.; Barlow, S.; Hu, Z.; McCord-Maughon, D.; Parker, T.; Rockel, H.; Thayumanavan, S.; Marder, S.; Beljonne, D.; Bredas, J. J. Am. Chem. Soc. 2000, 122, 9500-9510.

(9) Mosmann, T. J. Immunol. Methods. 1983, 65, 55-63.

(10) Tang, J.; Kong, B.; Wu, H.; Xu, M.; Wang, Y.; Wang,Y.; Zhao, D.; Zheng, G.; Adv. Mater. 2013, 25, 6569-6574. 


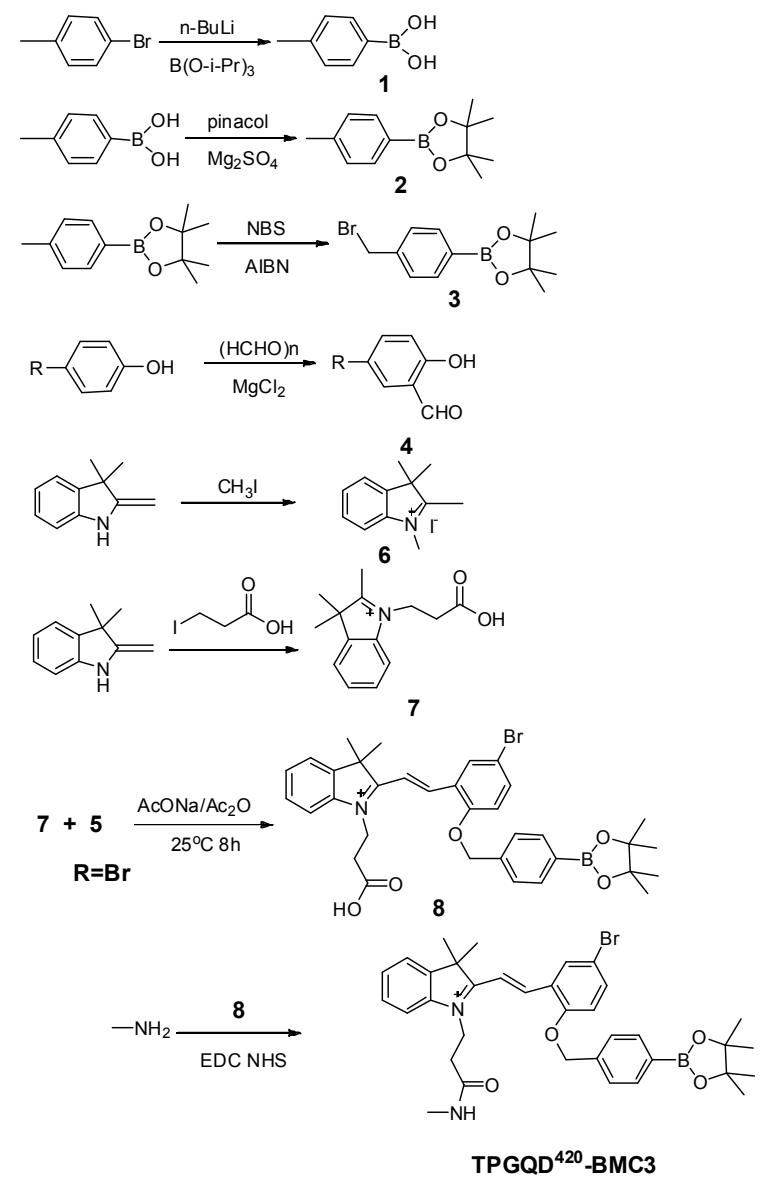

Scheme S1. Synthetic Routes of compounds 1-4, compounds 6-8 and TPGQD ${ }^{420}$-BMC3.

\begin{tabular}{ccccc}
\hline Sample & $-\mathbf{R}$ & BDES, $\mathbf{k J} \cdot \mathbf{m o l}^{\mathbf{1}}$ & Bond-length, $\mathbf{p m}$ & $\Delta \boldsymbol{E}_{\text {(Luмо-номо), }} \mathbf{e V}$ \\
\hline $\mathrm{BMC1}$ & $-\mathrm{H}$ & 236.38 & 146.07 & 2.5910 \\
$\mathrm{BMC2}$ & $-\mathrm{CF}_{3}$ & 213.14 & 146.45 & 2.4092 \\
$\mathrm{BMC3}$ & $-\mathrm{Br}$ & 223.43 & 146.30 & 2.5651 \\
$\mathrm{BMC4}$ & $-\mathrm{OCH}_{3}$ & 240.54 & 145.99 & 2.7960 \\
\hline
\end{tabular}

Table S1. The $\mathrm{CO}-\mathrm{CH}_{2}$ Bond Lengths (in pm) Bond Dissociation Energies (BDES) $\left(\mathrm{kJ} \cdot \mathrm{mol}^{-1}\right.$ ) and $\Delta E_{(\text {LUMO-HOMO) }}$ of BMC1-4 Determined by DFT Calculations. 


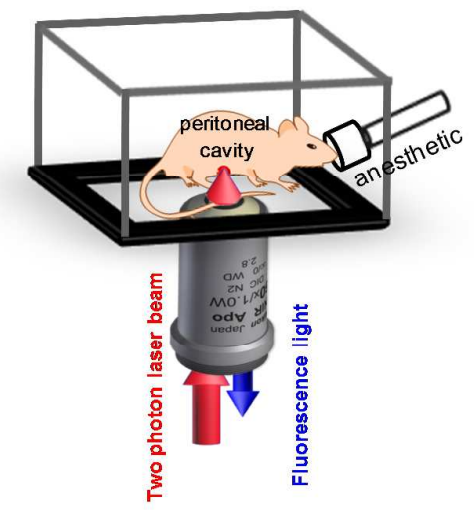

Figure S1. Schematic diagram of experimental set-up for in vivo ratiometric TPM images of endogenous $\mathrm{H}_{2} \mathrm{O}_{2}$ levels in inflamed mice.

A

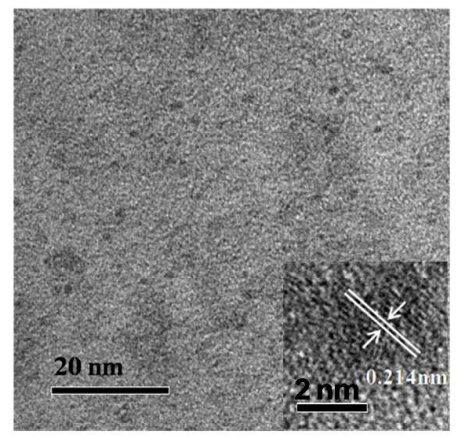

B
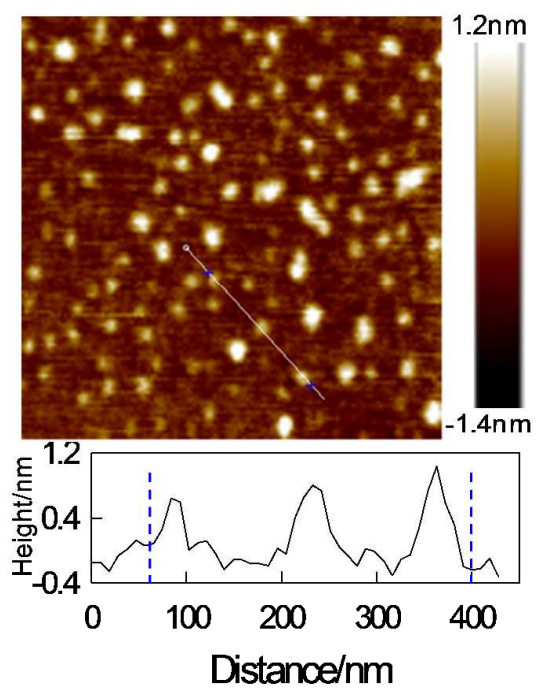

Figure S2. (A) TEM image of TPGQD ${ }^{420}$. Inset: magnified images of TPGQD ${ }^{420}$. (B) AFM topography image of TPGQD ${ }^{420}$ on mica substrates with the height profiles along the line in the image.
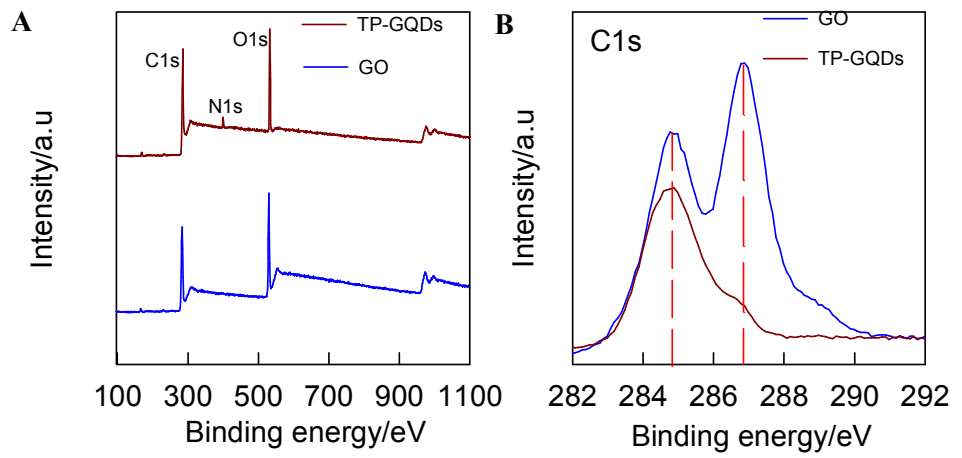

Figure S3. (A) XPS survey spectra of GO and TPGQD ${ }^{420}$. (B) High-resolution C1s XPS 
spectra of GO and TPGQD ${ }^{420}$.

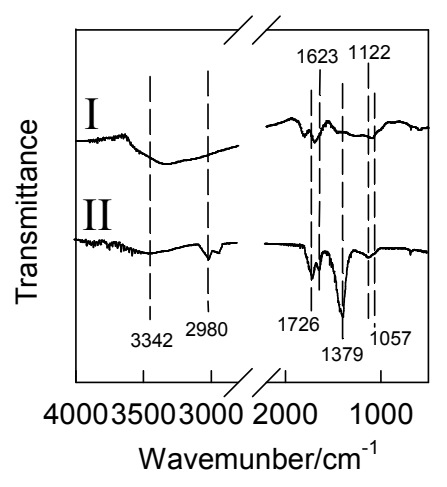

Figure S4. FT-IR spectra of (I) GO, (II) TPGQD ${ }^{420}$.
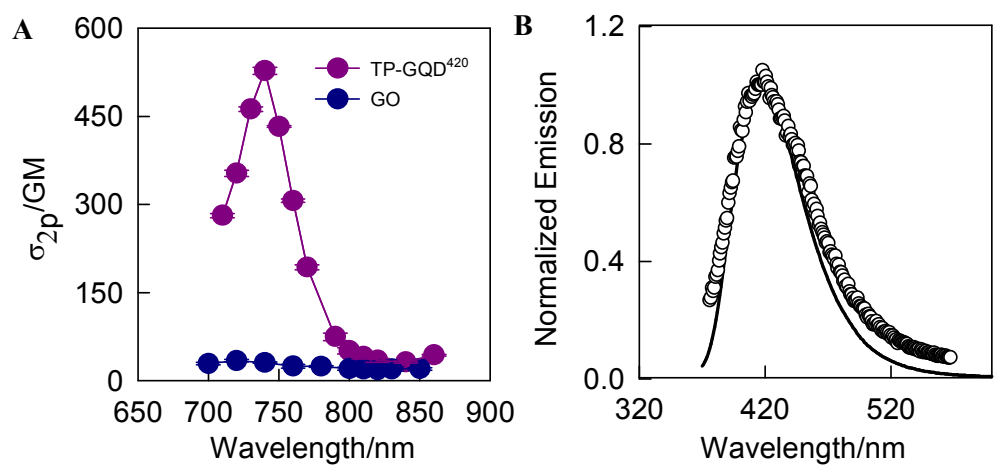

Figure S5. (A) Two-photon action cross sections of TPGQD ${ }^{420}$ and GO. (B) One photon (solid line, $\lambda_{\mathrm{ex}}=350 \mathrm{~nm}$ ) and two-photon (circle, $\lambda_{\mathrm{ex}}=740 \mathrm{~nm}$ ) luminescence spectra of the TPGQD $^{420}$.
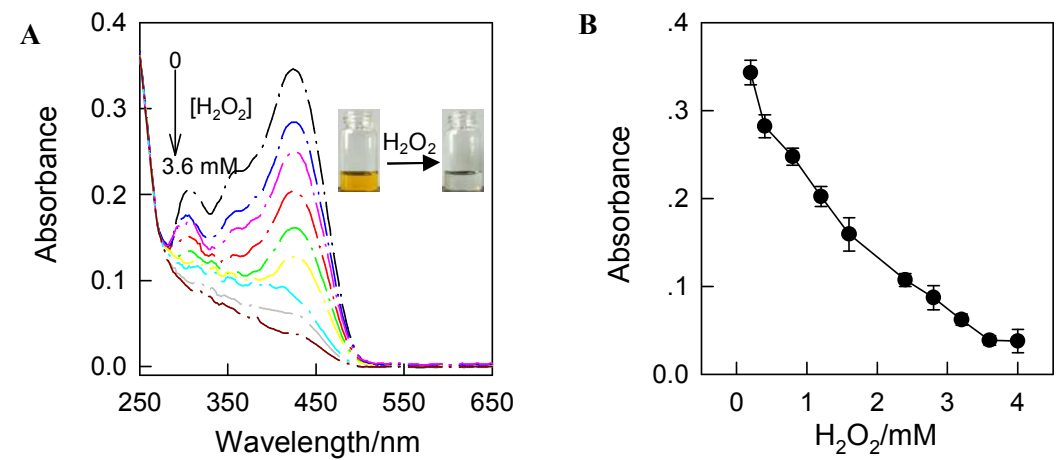

Figure S6. (A) UV-vis absorption spectra of $360 \mu \mathrm{M}$ BMC3 in PBS buffer solution (pH 7.4) upon addition of different concentrations of $\mathrm{H}_{2} \mathrm{O}_{2}$. The down arrow indicates the signal 
changes with the increases in $\mathrm{H}_{2} \mathrm{O}_{2}$ concentration $(0,0.4,0.8,1.2,1.6,1.8,2.4,2.8,3.2,3.6$ $\mathrm{mM}$ ). Inset: color change of $\mathrm{BMC} 3$ after treatment with $\mathrm{H}_{2} \mathrm{O}_{2}$. (B) The corresponding relationship between the maximum absorbance intensity and the $\mathrm{H}_{2} \mathrm{O}_{2}$ concentrations

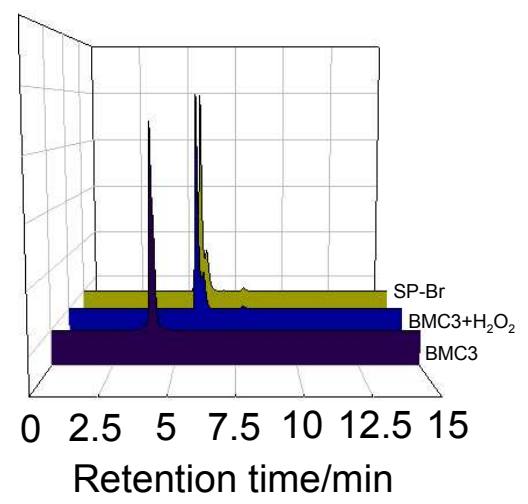

Figure S7. The reaction mechanism between BMC3 and $\mathrm{H}_{2} \mathrm{O}_{2}$ was verified by HPLC retention time detection. The product (SP-Br) of BMC3 $(360 \mu M)$ reaction with $\mathrm{H}_{2} \mathrm{O}_{2}(3.6 \mathrm{mM})$ was determined. The retention time of the product (SP-Br) is 5.74 the same as the standard material $\mathrm{Sp}-\mathrm{Br}$.

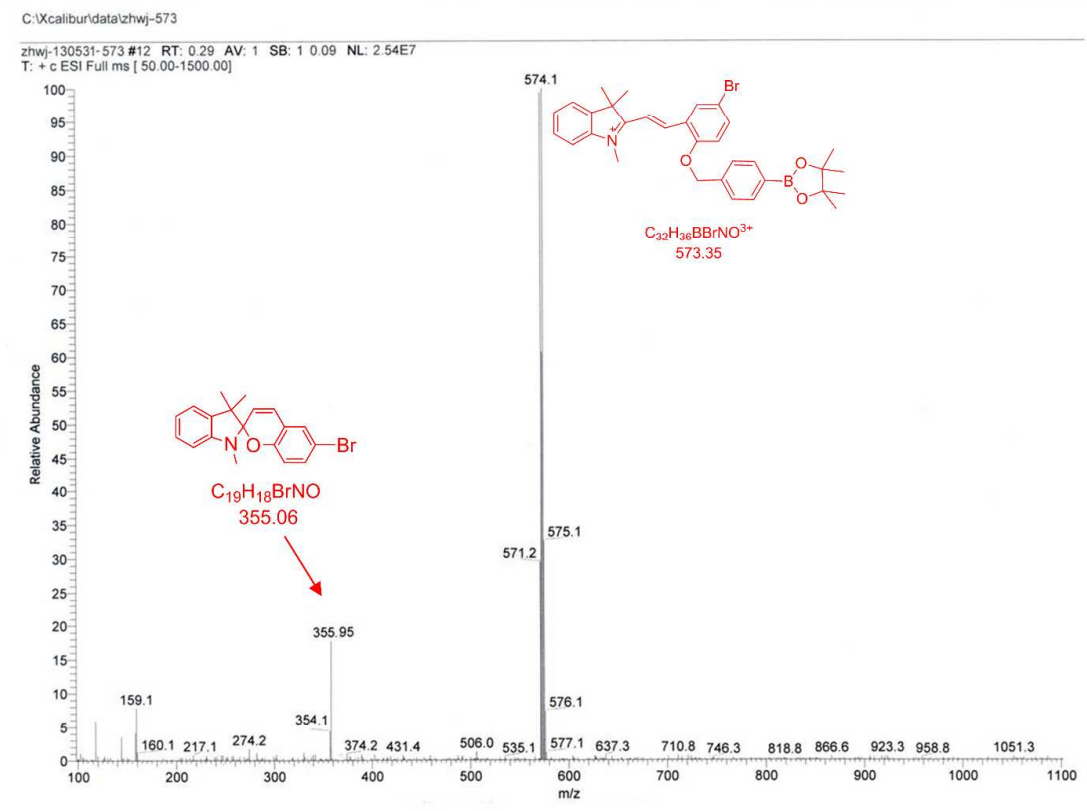

Figure S8. Mass spectrum of the product (SP-Br) of BMC3 reacted with $\mathrm{H}_{2} \mathrm{O}_{2}$. 


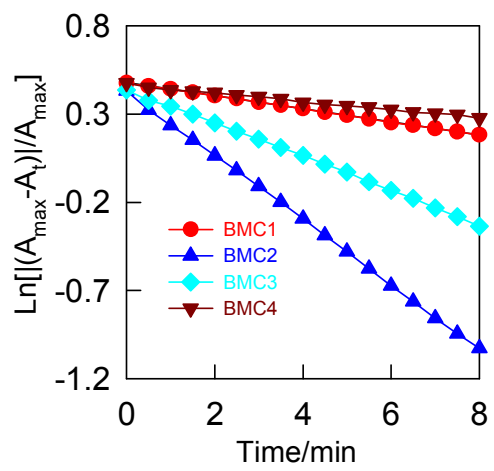

Figure S9. Kinetic plot of reaction of $360 \mu \mathrm{M}$ BMC1-4 with $3.6 \mathrm{mM} \mathrm{H}_{2} \mathrm{O}_{2}$ in PBS buffer (20mM, 10\% DMF, $\mathrm{pH}=7.4)$.

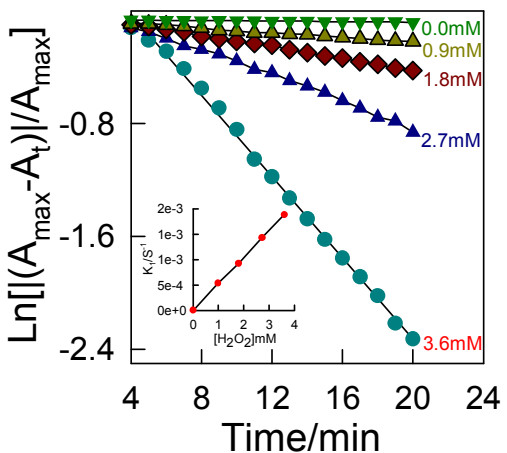

Figure S10. Plots of $\operatorname{Ln}\left[\left|\left(A_{\max }-A_{t}\right)\right| / A_{\max }\right]$ vs time for the reaction of BMC3 with different concentrations $\mathrm{H}_{2} \mathrm{O}_{2}(0-3.6 \mathrm{mM})$ in PBS buffer $\left(20 \mathrm{mM}, 10 \%\right.$ DMF, $\mathrm{pH}$ 7.4). Inset: Plot of $\mathrm{k}_{1}$ vs concentration of $\mathrm{H}_{2} \mathrm{O}_{2}$.

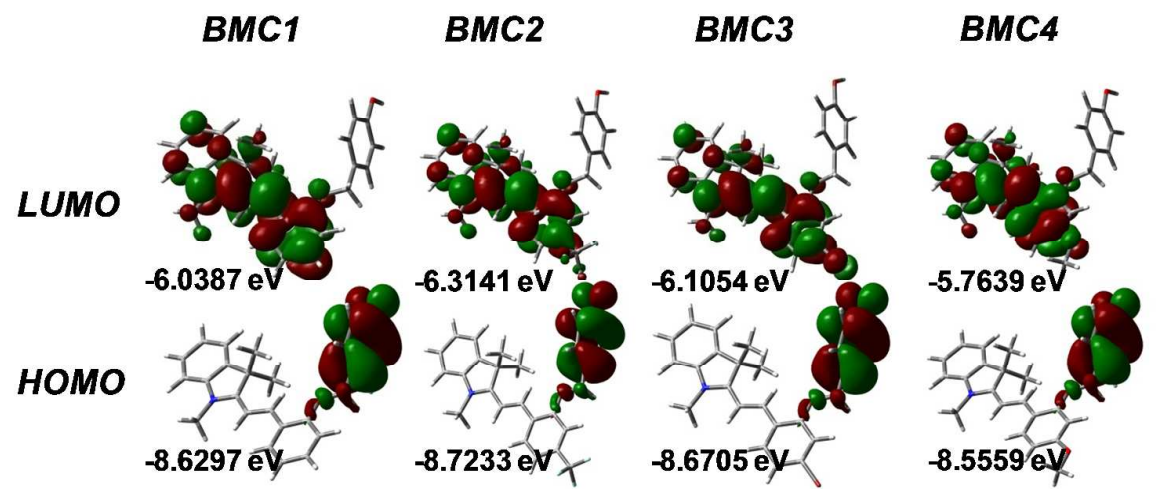

Figure S11. DFT optimized structures and molecular orbital plots (LUMO and HOMO) of BMC1-4 based on the optimized ground-state geometry. In the ball-and-stick representation, carbon, nitrogen, and oxygen atoms are colored in gray, blue, and red, respectively. 

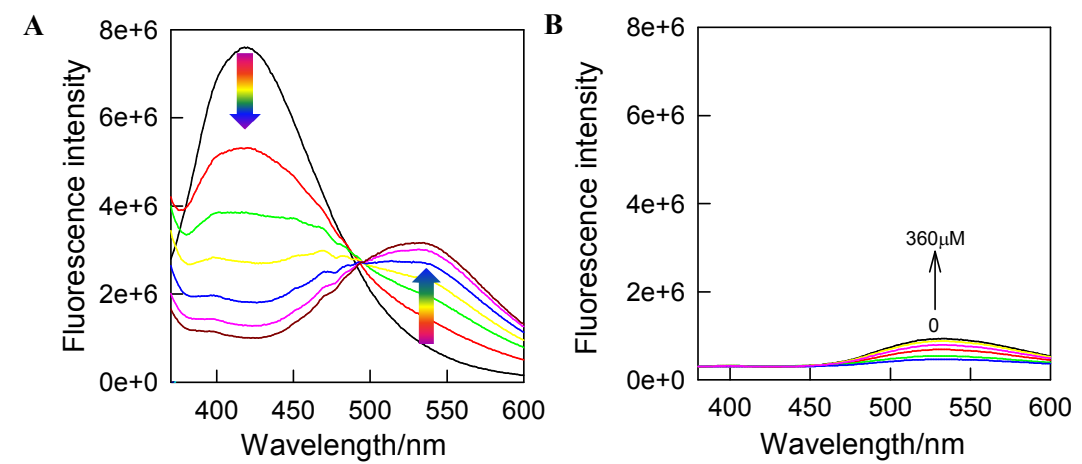

Figure S12. (A) Fluorescence emission changes of TPGQD ${ }^{420}\left(1.46 \mu \mathrm{g} \mathrm{mL}^{-1}\right)$ in PBS buffer solution (20mM, 10\% DMF, $\mathrm{pH} 7.4$ ) upon addition of different concentrations of BMC3. The arrows indicate the signal changes with increases in BMC3 concentrations $(0,60,120,180$, 240, 300 and $360 \mu \mathrm{M}$ ). $\lambda_{\mathrm{ex}}=350 \mathrm{~nm}$. (B) Fluorescence intensity records in PBS buffer solution (20 mM, 10\% DMF, pH 7.4) upon additions of different concentrations of BMC3 The arrow indicates the signal changes with increases in BMC3 concentrations $(0,60,120$, $180,240,300$ and $360 \mu \mathrm{M}) . \lambda_{\mathrm{ex}}=350 \mathrm{~nm}$.

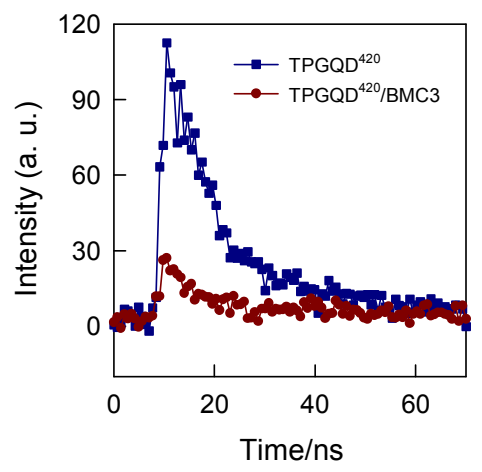

Figure S13. The time-resolved emission decays of $\operatorname{TPGQD}^{420}(1.46 \mu \mathrm{g} \mathrm{mL}-1)$ and TPGQD ${ }^{420} /$ BMC3 mixture (TPGQD $^{420}(1.46 \mu \mathrm{g}$ mL-1), BMC3 $(360 \mu \mathrm{M}))$ in PBS buffer solution (20 mM, 10\% DMF, pH 7.4). $\lambda \mathrm{ex}=350 \mathrm{~nm} ; \lambda \mathrm{em}=420 \mathrm{~nm}$.

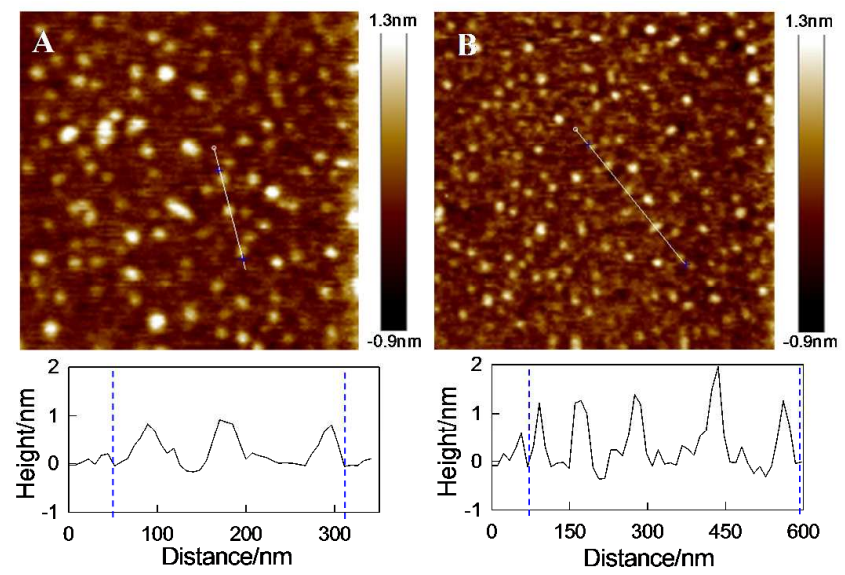


Figure S14. AFM images (top panel) acquired in air under tapping mode and the height profiles (down panel) of (A) TPGQD ${ }^{420}$ and (B) TPGQD ${ }^{420}$-BMC3. Scale bar: $0.4 \mu \mathrm{m}$.

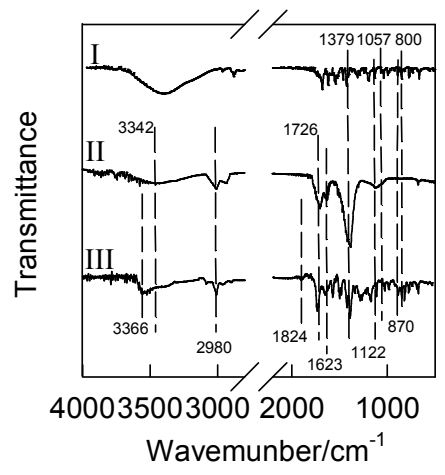

Figure S15. FT-IR spectra of (I) BMC3, (II) TPGQD ${ }^{420}$ and (III) TPGQD ${ }^{420}-\mathrm{BMC}^{2}$ were compared each other.
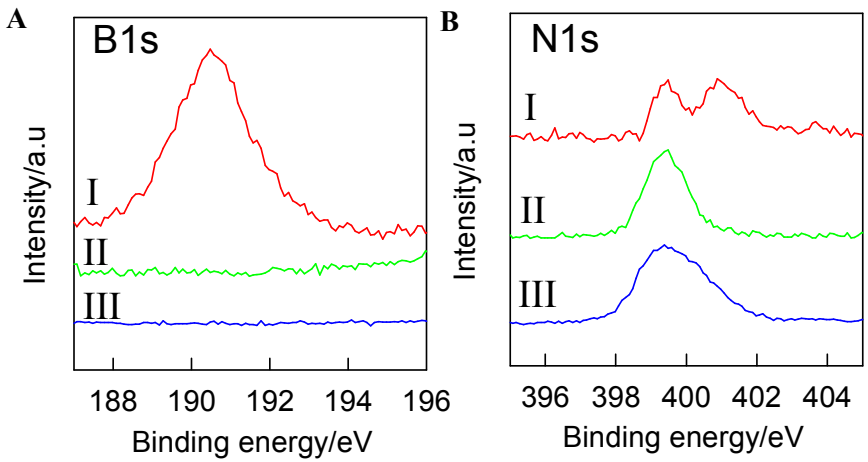

Figure S16. XPS spectra for (A) B 1s, (B) $\mathrm{N} 1 \mathrm{~s}$ obtained at (I) TPGQD ${ }^{420}-\mathrm{BMC}$, (II) TPGQD ${ }^{420}-\mathrm{BMC}+\mathrm{H}_{2} \mathrm{O}_{2}$, (III) TPGQD ${ }^{420}$.
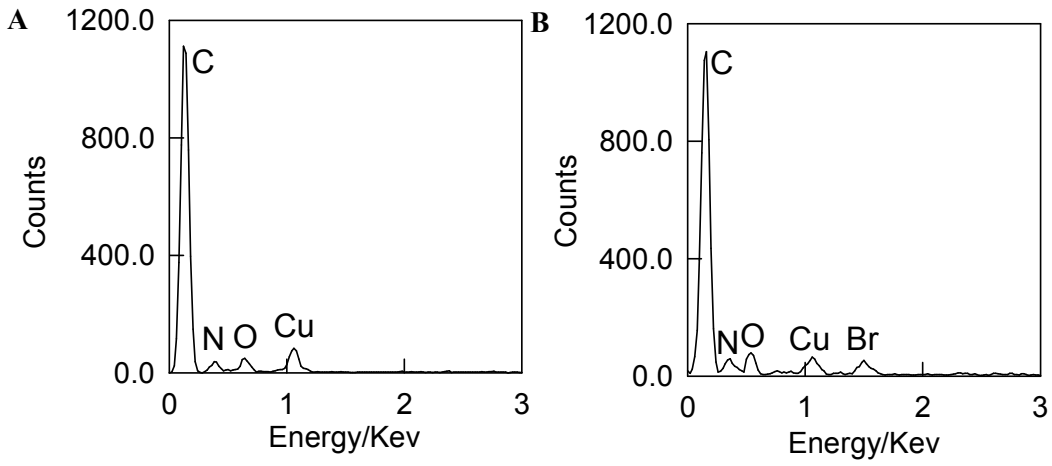

Figure S17. EDX data of TPGQD ${ }^{420}(\mathrm{~A})$ and TPGQD ${ }^{420}-\mathrm{BMC} 3(\mathrm{~B})$. 


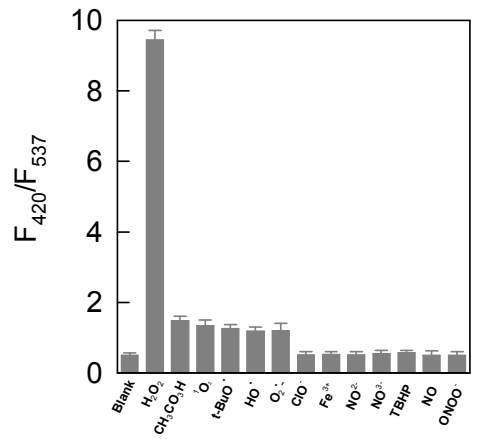

Figure S18. Fluorescence responses of TPGQD ${ }^{420}$-BMC3 $\left(7.2 \mu \mathrm{g} \mathrm{mL}^{-1}\right)$ treated by various kinds of reactive oxygen species (ROS). Plot of $\mathrm{R}=\mathrm{F}_{420} / \mathrm{F}_{537}$ as a function of the ROS at 40 $\mu \mathrm{M}$. Data were acquired in PBS buffer (20mM, 10\% DMF, $\mathrm{pH}=7.4)$.
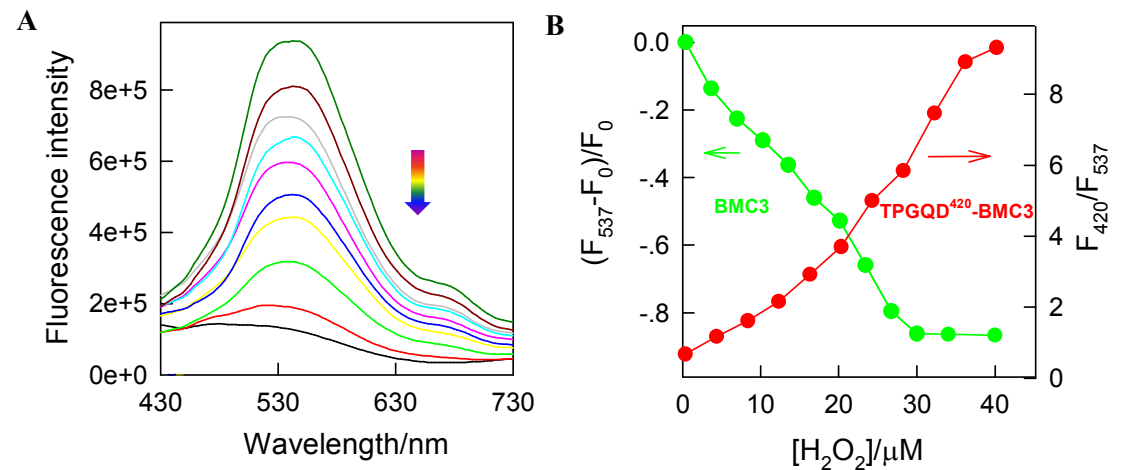

Figure S19. (A) Fluorescence spectra of $360 \mu \mathrm{M}$ BMC3 in PBS buffer solution (20mM, 10\% DMF, $\mathrm{pH}=7.4$ ) upon addition of different concentrations of $\mathrm{H}_{2} \mathrm{O}_{2}$. The down arrow indicates the signal changes with the increases in $\mathrm{H}_{2} \mathrm{O}_{2}$ concentration $(0.4,3.0,6.0,10.0,13.0,16.0$, 20.0, 23, 26, $30 \mu \mathrm{M}$ ). (B) The fluorescence response of BMC3 (Green line) and TPGQD ${ }^{420}$-BMC3 (Red line) treated by the different concentrations of $\mathrm{H}_{2} \mathrm{O}_{2}$.

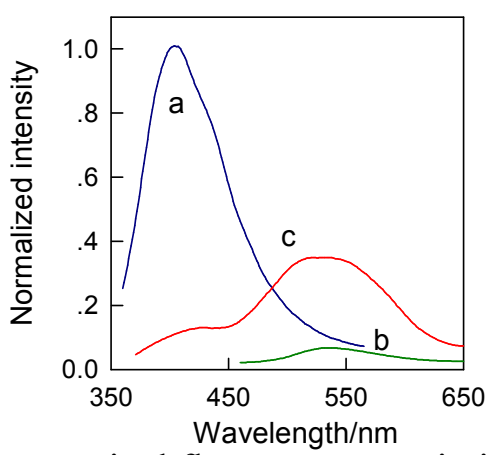

Figure S20. Normalized two-photon excited fluorescence emission spectra of TPGQD ${ }^{420}$ (a), BMC3 (b) and the TPGQD ${ }^{420}$-BMC3 conjugates (c) in PBS buffer solution $(20 \mathrm{mM}, 10 \%$ 
DMF, $\mathrm{pH}=7.4) . \lambda_{\mathrm{ex}}=740 \mathrm{~nm}$.

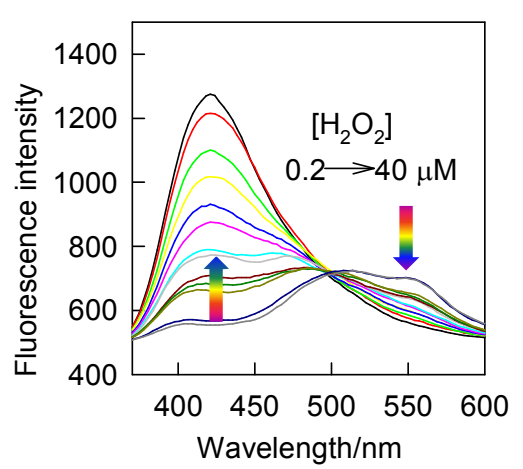

Figure S21. Two-photon excited fluorescence emission spectra for the titration of TPGQD ${ }^{420}$-BMC3 $(0.05 \mu \mathrm{g} / \mathrm{mL})$ treated with different concentration of $\mathrm{H}_{2} \mathrm{O}_{2}(0.2-40 \mu \mathrm{M})$. $\lambda_{\mathrm{ex}}=740 \mathrm{~nm}$.

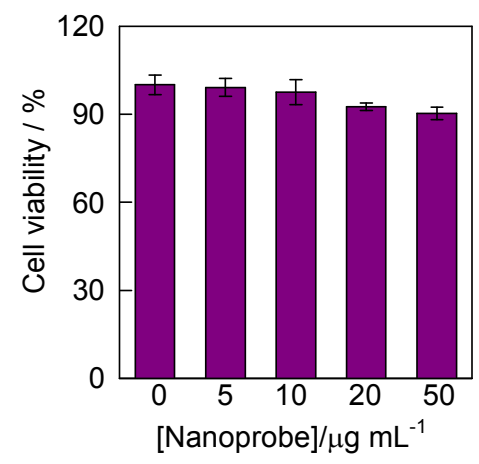

Figure S22. Cell viability of HeLa cells after $24 \mathrm{~h}$ treated with different concentrations of TPGQD ${ }^{420}$-BMC3@PEG at $37{ }^{\circ} \mathrm{C}$.
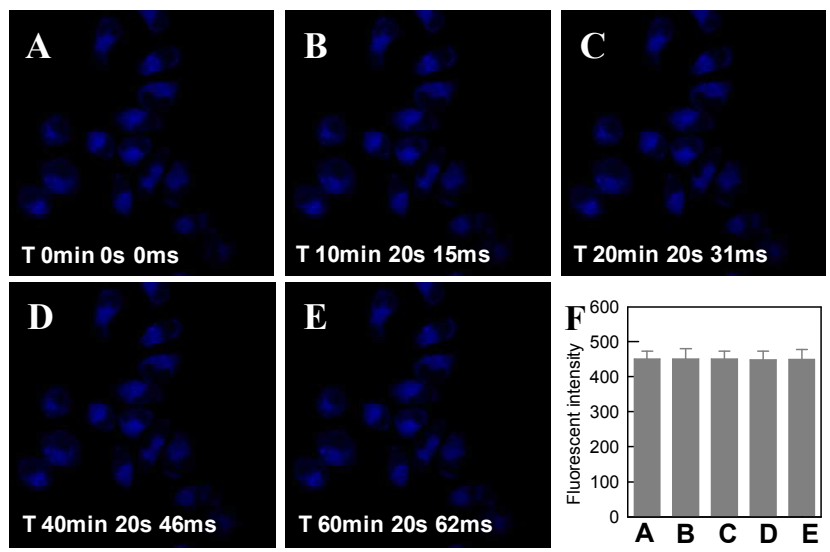

Figure S23. (A-E) Two photon images of HeLa cells treated by TPGQD ${ }^{420}-\mathrm{BMC} @ \mathrm{PEG}$ in the presence of $\mathrm{H}_{2} \mathrm{O}_{2}$ were recorded with $600 \mathrm{sec}$ intervals for the duration of one hour using xyt mode under continuous irradiation by the fs-pulses. (F) Quantification and comparison of the relative fluorescence intensity of parts A-E correspondingly. Each data was obtained from 
cells in the scanned area and collected in blue channel $(400-450 \mathrm{~nm})$.

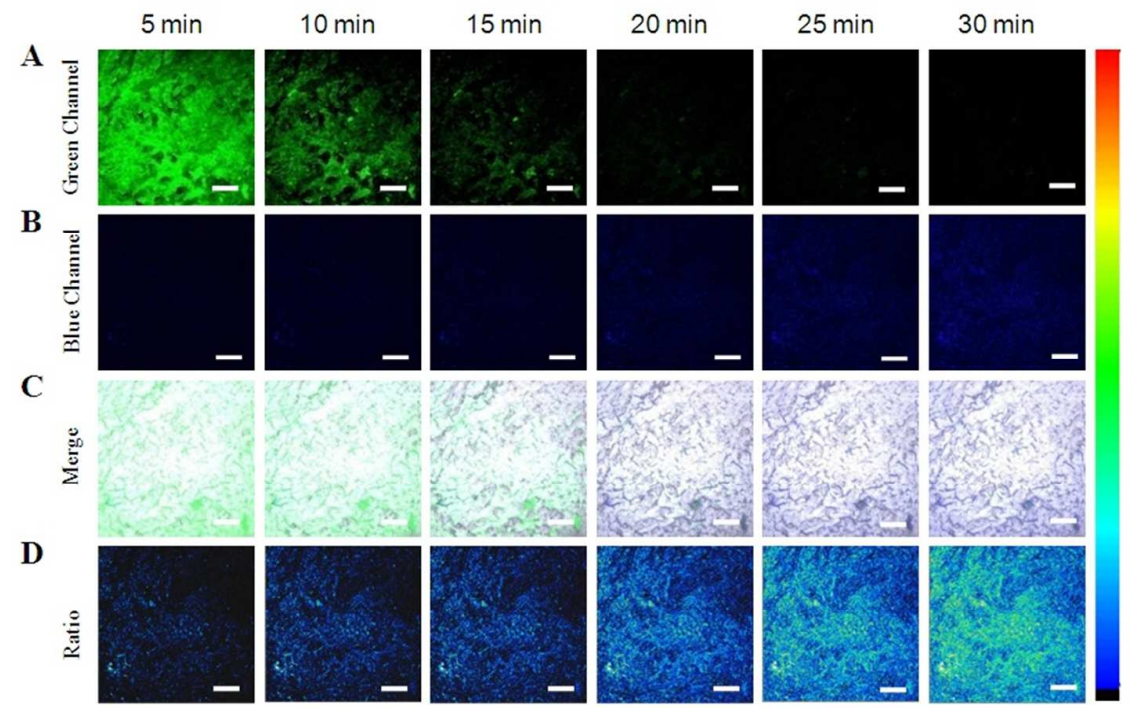

Figure S24. Ratiometric two-photon microscopy images $\left(\mathrm{F}_{\text {blue }} / \mathrm{F}_{\text {green }}\right)$ of cervical tumor tissue slice stained with TPGQD ${ }^{420}$-BMC3@PEG at different times. The fluorescence signals were collected in two channels: blue channel (A, 400-450 nm) and green channel (B, 500-550 nm) upon excitation at $740 \mathrm{~nm}$. The (C) row exhibits the corresponding composite images between bright field and two channels. The ratio images in the (D) row were acquired by Image-Pro Plus software. Scale bars: $200 \mathrm{~mm}$.

\section{Synthesis}

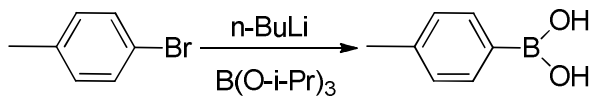

Preparation of p-tolylboronic acid In a typical procedure an oven-dried $250 \mathrm{~mL}$ two-neck round bottomed flask with magnetic stirrer was equipped with a rubber septum and allowed to cool under a dry nitrogen atmosphere. Dry THF $(125 \mathrm{~mL})$ was then added via cannulation. 1-bromo-4-methylbenzene, purified via passing neat through a short plug of neutral alumina (Brockmann I, 50-200 $\mu \mathrm{m}$ ) prior to use $(7.18 \mathrm{~g}, 5.17 \mathrm{~mL}, 42.0 \mathrm{mmol})$ was then injected into the flask, and the stirred solution was cooled to $-78{ }^{\circ} \mathrm{C}$. After 10 minutes a solution of 
n-butyllithium (16.8 mL, 2.5 M in hexanes, $42 \mathrm{mmol}$ ) was added dropwise over a period of 10 minutes. The solution was then allowed to warm slightly to ensure thorough mixing of the lithium salts, and stirred at $-78{ }^{\circ} \mathrm{C}$ for a further 1.5 hours. Triisopropyl borate $(9.70 \mathrm{~mL}, 42.0$ mmol) was then added dropwise over 10 minutes, after which the solution was stirred for a further 1.5 hours before being allowed to warm to approximately $0-10{ }^{\circ} \mathrm{C}$, whereupon water $(10 \mathrm{~mL})$ was added slowly. The resultant solution was then partitioned between water (100 $\mathrm{mL})$, saturated aqueous $\mathrm{NH}_{4} \mathrm{Cl}(15 \mathrm{~mL})$, and diethyl ether $(75 \mathrm{~mL})$. The organic components were separated and the aqueous layer washed with further diethyl ether $(3 \times 50 \mathrm{~mL})$. The organic layers were combined, dried $\left(\mathrm{MgSO}_{4}\right)$, and concentrated in vacuo. The resultant solid was further dried in a vacuum dessicator for 1-2 hours, to generate the title compound as a white to off-white powder (4.85 g, 85\% yield), which was used without further purification.

${ }^{1} \mathrm{H}$ NMR (400MHz, $\mathrm{CDCl}_{3}$ ): $\delta \square \square 8.13(\mathrm{~d}, J=7.7 \mathrm{~Hz}, 2 \mathrm{H}), 7.32(\mathrm{~d}, J=7.7 \mathrm{~Hz}, 2 \mathrm{H}), 2.45$ (s, $3 \mathrm{H}) ;{ }^{13} \mathrm{C}$ NMR $\left(100 \mathrm{MHz}, \mathrm{CDCl}_{3}\right): \delta 143.1,135.9,128.9,22.1$; ESI-HRMS (m/z): calcd for $\mathrm{C}_{7} \mathrm{H}_{8} \mathrm{BO}_{2}[\mathrm{M}]+135.96$, found: 136.2

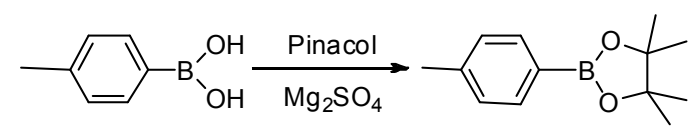

Preparation of 4,4,5,5-tetramethyl-2-p-tolyl-1,3,2-dioxaborolane In a typical procedure, to a $100 \mathrm{~mL}$ round bottom flask fitted with a magnetic stirrer was added ptolylboronic acid (4.89 $\mathrm{g}, 36.0 \mathrm{mmol})$, anhydrous pinacol (4.68 g, $39.6 \mathrm{mmol})$, and diethyl ether $(50 \mathrm{~mL})$. After stirring for 5 minutes $\mathrm{MgSO}_{4}(5 \mathrm{~g})$ was added and the flask sealed with a rubber septum. The reaction was stirred vigorously overnight at room-temperature, the solids were then removed by filtration, and washed with diethyl ether $(3 \times 25 \mathrm{~mL})$. The crude filtrate was then 
concentrated in vacuo and redissolved in petrol, before being passed through a plug of silica slurried with petrol. The silica was washed with further portions of petrol and the resultant solution was concentrated in vacuo and thoroughly dried under vacuum to generate the title compound as a white crystalline solid ( $7.81 \mathrm{~g}, 99.5 \%$ yield) which was used without further purification. If necessary the product was forced to crystallise by cooling the flask briefly on a bed of dry-ice. ${ }^{1} \mathrm{H}$ NMR $\left(400 \mathrm{MHz}, \mathrm{CDCl}_{3}\right): \delta 7.76(\mathrm{~d}, J=8.0 \mathrm{~Hz}, 2 \mathrm{H}), 7.22(\mathrm{~d}, J=8.2 \mathrm{~Hz}$, 2H), 2.40 (s, 3H), 1.37 (s, 12H); ${ }^{13} \mathrm{C}$ NMR (100MHz): $\delta 141.4,134.9,128.6,83.7,25.0,21.8$; ESI-HRMS (m/z): calcd for $\mathrm{C}_{13} \mathrm{H}_{19} \mathrm{BO}_{2}[\mathrm{M}]^{+} 218.10$, found: 218.20

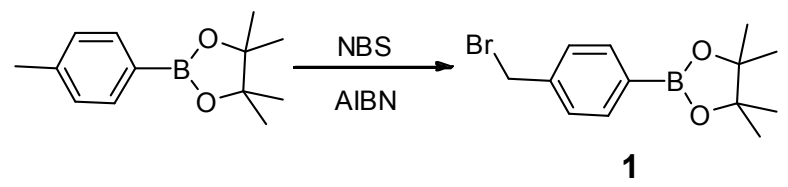

Preparation of 2-(4-(bromomethyl)phenyl)-4,4,5,5-tetramethyl-1,3,2-dioxaboro lane (1) In a typical procedure, to a $500 \mathrm{~mL}$ round bottom flask fitted with a magnetic stirrer was added 4,4,5,5-tetramethyl-2-p-tolyl-1,3,2-dioxaborolane $\quad(7.42 \quad \mathrm{~g}, \quad 34.0 \mathrm{mmol})$, N-bromosuccinimide $(6.05 \mathrm{~g}, 34.0 \mathrm{mmol})$, and acetonitrile $(250 \mathrm{~mL})$. The solution was stirred for 5 minutes prior to the addition of AIBN (112 mg, $0.68 \mathrm{mmol}, 2 \mathrm{~mol} \%$ ). A condensor was then fitted to the flask and the solution refluxed at $90{ }^{\circ} \mathrm{C}$ for 4 hours under an air atmosphere. After cooling to room temperature the solution was concentrated on a rotary evaporator, using two portions of ethyl acetate $(75 \mathrm{~mL})$ to azeotropically remove the remaining acetonitrile. The crude material was then slurried with petrol $(25 \mathrm{~mL})$ and filtered through a plug of silica, eluting with petrol. The resulting solution was then concentrated in vacuo, and dried under high vacuum if necessary. The crystalline product that formed was then washed with a small 
amount of petrol and recrystallised from minimal petrol to generate the title compound as large colourless crystals $(7.17 \mathrm{~g}, 71 \%$ yield $)$. Careful recrystallization of the retained mother-liqours and washes yielded further product upon concentration and cooling $(0.92 \mathrm{~g}, 9 \%$ yield; total $80 \%$ yield). ${ }^{1} \mathrm{H}$ NMR $\left(400 \mathrm{MHz}, \mathrm{CDCl}_{3}\right): \delta 7.79(\mathrm{~d}, J=8.2 \mathrm{~Hz}, 2 \mathrm{H}) 7.39(\mathrm{~d}, J=8.2$ $\mathrm{Hz}, 2 \mathrm{H}), 4.49$ (s, 2H) 1.34 (s, 12H); ${ }^{13} \mathrm{C}$ NMR (100MHz, $\left.\mathrm{CDCl}_{3}\right): \delta 140.8,135.4,128.4,84.0$, 33.4, 25.0; EI-MS (m/z): calcd for $\mathrm{C}_{13} \mathrm{H}_{18} \mathrm{BBrO}_{2}[\mathrm{M}]^{+}$297.00, found: 297.20

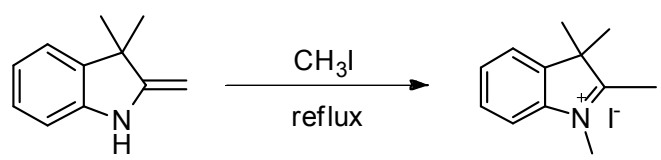

Preparation of N-Methyl-2, 3, 3-trimethylindolenine. In a typical procedure, to a $100 \mathrm{~mL}$ round bottom flask a mixture of 2,3,3-trimethylindolenine $(0.79 \mathrm{~g}, 5.0 \mathrm{mmol})$ and iodomethane $(0.85 \mathrm{~g}, 0.61 \mathrm{mmol})$ was heated to $50{ }^{\circ} \mathrm{C}$ for $2 \mathrm{~h}$ under $\mathrm{N}_{2}$. After cooling the solution to room temperature, yellow crystals were collected by filtration. The solid was washed with ethanol and diethyl ether successively. The solvent was removed under vacuum, and the residue was recrystalized from absolute ethanol to give the product ( $1.05 \mathrm{~g}, 70 \%$ yield) ${ }^{1} \mathrm{H}$ NMR (400MHz, DMSO): $\delta 7.92(\mathrm{~m}, 1 \mathrm{H}), 7.83(\mathrm{dd}, J=2,1 \mathrm{H}), 7.62(\mathrm{dd}, J=2.8,2 \mathrm{H}), 2.97$ (s, 3H), 2.77 (s, 3H), 1.53 (s, 6H). ${ }^{13} \mathrm{C}$ NMR (100MHz, DMSO): $\delta$ 196.2, 142.3, 141.8, 129.5, 129.0, 123.5, 115.4, 54.2, 35.0, 21.9, 14.5. EI-MS (m/z): calcd for $\mathrm{C}_{12} \mathrm{H}_{16} \mathrm{~N}[\mathrm{M}]^{+} 174.26$, found: 174.00

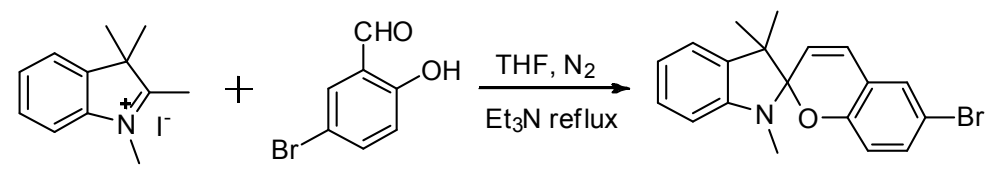


Preparation of SP-Br. 1,2,3,3-tetramethyl-3H-indol-1-ium iodide (335 mg, $1.11 \mathrm{mmol}$ ) was dissolved in freshly distilled EtOH $(10 \mathrm{~mL})$ and anhydrous $\mathrm{Et}_{3} \mathrm{~N}(200 \mu \mathrm{L}, 1.43 \mathrm{mmol})$. 5-bromo-2-hydroxybenzaldehyde $(220 \mathrm{mg}, 1.09 \mathrm{mmol})$ was added and the reaction mixture was stirred under argon for 3 hours under reflux. After $3 \mathrm{~h}$ the solvent was removed under reduced pressure, the residue was dissolved in $\mathrm{CH}_{2} \mathrm{Cl}_{2}$ and dried over anhyd $\mathrm{Na}_{2} \mathrm{SO}_{4}$. The solvent was evaporated under reduced pressure, and the residue was dried in vacuo and purified by gradient flash chromatography on silica gel to the product as a pale pink solid (300 mg, 77\% yield). ${ }^{1} \mathrm{H}$ NMR (400MHz, $\left.\mathrm{CDCl}_{3}\right): \delta 7.15-7.27(\mathrm{~m}, 3 \mathrm{H}), 7.09(\mathrm{~d}, J=7.2$ $\mathrm{Hz}, 1 \mathrm{H}), 6.87$ (t, $J=7.4 \mathrm{~Hz}, 1 \mathrm{H}), 6.80(\mathrm{~d}, J=10.3 \mathrm{~Hz}, 1 \mathrm{H}), 6.61(\mathrm{~d}, J=9.2 \mathrm{~Hz}, 1 \mathrm{H}), 6.55(\mathrm{~d}, J$ $=7.7 \mathrm{~Hz}, 1 \mathrm{H}), 5.74(\mathrm{~d}, J=10.2 \mathrm{~Hz}, 1 \mathrm{H}), 2.74(\mathrm{~s}, 3 \mathrm{H}), 1.32(\mathrm{~s}, 3 \mathrm{H}), 1.18(\mathrm{~s}, 3 \mathrm{H}) .{ }^{13} \mathrm{C} \mathrm{NMR}$ $\left(100 \mathrm{MHz}, \mathrm{CDCl}_{3}\right): 153.6,148.0,136.5,132.2,129.1,128.4,127.7,121.5,120.7,120.6,119.3$, $116.9,111.8,106.9,104.5,51.9,28.9,25.9,20.1$. EI-MS $(\mathrm{m} / \mathrm{z})$ : calcd for $\mathrm{C}_{19} \mathrm{H}_{18} \mathrm{BrNO}$ : 356.26; found: 357.00 .

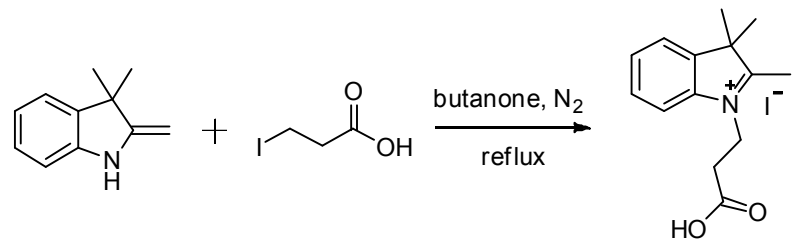

Preparation of 1-(2-carboxyethyl)-2,3,3-trimethyl-3H-indol-1-ium iodide: 2,3,3-trimethylindolenine $(5.01 \mathrm{~mL}, 30.59 \mathrm{mmol})$ and 3-iodopropanic acid $(6.35 \mathrm{~g}, 30.17$ mmol) were diluted in $10 \mathrm{~mL}$ butanone and stirred under argon for 5 hours under reflux. The precipitate was suspended in $50 \mathrm{~mL} \mathrm{H} \mathrm{H}_{2} \mathrm{O}$ and washed three times with $50 \mathrm{~mL}$ DCM. The organic layers were combined and washed three times with $25 \mathrm{~mL}$ water. The aqueous layers were combined, filtered and the solvent removed at high vacuum, receiving the product as 
pale yellow solid (10.52 g, $97 \%$ yield). ${ }^{1} \mathrm{H}$ NMR (400MHz, DMSO): $\delta 1.55$ (s, 6H), 2.89 (s, $3 \mathrm{H}), 3.00(\mathrm{t}, J=6.88 \mathrm{~Hz}, 2 \mathrm{H}), 4.67(\mathrm{t}, J=6.76 \mathrm{~Hz}, 2 \mathrm{H}), 7.64-7.58(\mathrm{~m}, 2 \mathrm{H}), 7.84-7.89(\mathrm{~m}, 1 \mathrm{H})$, 7.97-8.03 (m, 1H). ${ }^{13} \mathrm{C}$ NMR (100MHz, DMSO): $\delta$ 197.99, 171.66, 141.83, 140.93, 129.43, 129.01, 123.57, 115.65, 54.34, 43.58, 31.17, 21.95, 14.39. EI-MS (m/z): calcd for $\mathrm{C}_{14} \mathrm{H}_{18} \mathrm{NO}_{2}^{+}$: 232.30; found: 232.10 .

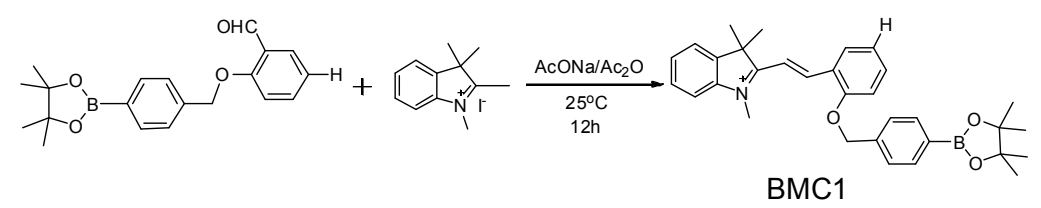

Synthesis of BMC1.A mixture of 2-((4-(4,4,5,5-tetramethyl-1,3,2-dioxaborolan-2-yl) benzyl)oxy)benzaldehyde $(0.067 \mathrm{mmol})$, 1,2,3,3-tetramethyl-3H-indolium iodide $(0.2994 \mathrm{~g}$, $0.0994 \mathrm{mmol})$ and sodium acetate $(0.0816 \mathrm{~g}, 0.0994 \mathrm{mmol})$ was reacted in acetic anhydride $(20 \mathrm{~mL})$ according to general procedure to give BMC1 $(89 \%)$ as a dark brown solid. ${ }^{1} \mathrm{H}$ $\mathrm{NMR}\left(400 \mathrm{MHz}, \mathrm{CDCl}_{3}\right): \delta 8.45(\mathrm{~d}, J=16.5 \mathrm{~Hz}, 1 \mathrm{H}), 8.33(\mathrm{~d}, J=2.4 \mathrm{~Hz}, 1 \mathrm{H}), 7.87(\mathrm{~d}, J=8.1$ $\mathrm{Hz}, 2 \mathrm{H}), 7.73(\mathrm{~d}, J=16.5 \mathrm{~Hz}, 1 \mathrm{H}), 7.65(\mathrm{dd}, J=5.9,3.1 \mathrm{~Hz}, 1 \mathrm{H}), 7.60(\mathrm{~d}, J=2.4 \mathrm{~Hz}, 1 \mathrm{H})$, $7.58-7.55(\mathrm{~m}, 2 \mathrm{H}), 7.54-7.50(\mathrm{~m}, 2 \mathrm{H}), 7.47(\mathrm{~d}, J=8.0 \mathrm{~Hz}, 2 \mathrm{H}), 6.97(\mathrm{~d}, J=8.9 \mathrm{~Hz}, 1 \mathrm{H})$, $5.21(\mathrm{~d}, J=6.5 \mathrm{~Hz}, 2 \mathrm{H}), 4.31(\mathrm{~s}, 3 \mathrm{H}), 1.76(\mathrm{~s}, 6 \mathrm{H}), 1.36(\mathrm{~s}, 12 \mathrm{H}) .{ }^{13} \mathrm{C} \mathrm{NMR}(100 \mathrm{MHz}$, $\left.\mathrm{CDCl}_{3}\right): \delta 182.65,158.97,149.58,142.84,141.48,138.81,136.13,135.20,131.54,129.73$, $129.62,126.75,123.03,122.43,122.37,114.82,112.85,112.52,84.02,70.85,52.28,36.87$, 27.07, 24.86. MS (ESI): $\mathrm{m} / \mathrm{z}$ calc. for $\mathrm{C}_{32} \mathrm{H}_{37} \mathrm{BNO}_{3}{ }^{+}: 494.45$; found: $494.2[\mathrm{M}]^{+}$

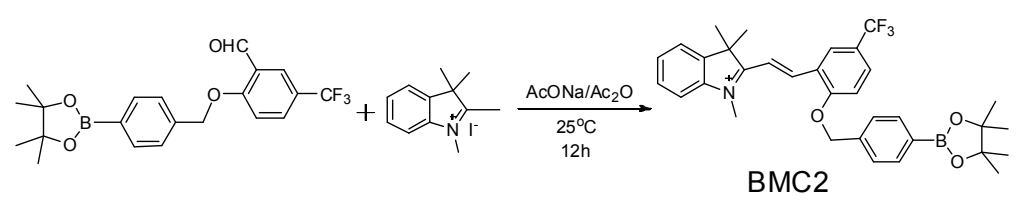


Synthesis of BMC2.A mixture of 2-((4-(4,4,5,5-tetramethyl-1,3,2-dioxaborolan-2-yl) benzyl)oxy)-5-(trifluoromethyl)benzaldehyde(0.067mmol),1,2,3,3-tetramethyl-3H-indolium iodide $(0.2994 \mathrm{~g}, 0.0994 \mathrm{mmol})$ and sodium acetate $(0.0816 \mathrm{~g}, 0.0994 \mathrm{mmol})$ was reacted in acetic anhydride $(20 \mathrm{~mL})$ according to general procedure to give BMC2 $(43 \%)$ as a dark yellow solid. ${ }^{1} \mathrm{H}$ NMR(400MHz, $\left.\mathrm{CDCl}_{3}\right): \delta 8.45(\mathrm{~d}, J=16.0 \mathrm{~Hz}, 1 \mathrm{H}), 8.25(\mathrm{~s}, 1 \mathrm{H}), 7.90(\mathrm{~d}, J$ $=7.4 \mathrm{~Hz}, 2 \mathrm{H}), 7.79(\mathrm{~d}, J=20.1 \mathrm{~Hz}, 2 \mathrm{H}), 7.64(\mathrm{~s}, 1 \mathrm{H}), 7.60(\mathrm{~s}, 2 \mathrm{H}), 7.53(\mathrm{~d}, J=7.1 \mathrm{~Hz}, 3 \mathrm{H})$, $7.19(\mathrm{~d}, J=9.1 \mathrm{~Hz}, 1 \mathrm{H}), 5.31(\mathrm{~s}, 2 \mathrm{H}), 4.25(\mathrm{~s}, 3 \mathrm{H}), 1.80(\mathrm{~s}, 6 \mathrm{H}), 1.38(\mathrm{~s}, 12 \mathrm{H}) .{ }^{13} \mathrm{C}$ NMR $(100$ $\left.\mathrm{MHz}, \mathrm{CDCl}_{3}\right): \delta 182.96,157.63,147.41,143.32,141.86,138.69,135.57,135.32,130.35$, $129.98,127.85,127.14,124.58,122.78,115.49,114.70,114.41,84.36,71.64,57.28,52.86$, 37.32, 27.23, 25.19. MS (ESI): m/z calc. for $\mathrm{C}_{33} \mathrm{H}_{36} \mathrm{BF}_{3} \mathrm{NO}_{3}{ }^{+}: 562.45$; found: $562.2[\mathrm{M}]^{+}$

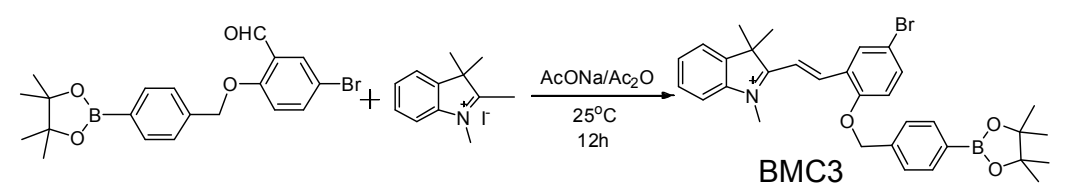

Synthesis of BMC3 A mixture of 5-bromo-2-((4-(4,4,5,5-tetramethyl-1,3,2Dioxaborolan-2-yl)benzyl)oxy)benzaldehyde(0.067mmol), 1,2,3,3-tetramethyl-3H-indoliumio dide $(0.2994 \mathrm{~g}, 0.0994 \mathrm{mmol})$ and sodium acetate $(0.0816 \mathrm{~g}, 0.0994 \mathrm{mmol})$ was reacted in acetic anhydride $(20 \mathrm{~mL})$ according to general procedure to give BMC3 $(83 \%)$ as a yellow solid. ${ }^{1} \mathrm{H}$ $\mathrm{NMR}\left(400 \mathrm{MHz}, \mathrm{CDCl}_{3}\right): \delta 8.45(\mathrm{~d}, J=16.5 \mathrm{~Hz}, 1 \mathrm{H}), 8.33(\mathrm{~d}, J=2.4 \mathrm{~Hz}, 1 \mathrm{H}), 7.87(\mathrm{~d}, J=8.1$ $\mathrm{Hz}, 2 \mathrm{H}), 7.73(\mathrm{~d}, J=16.5 \mathrm{~Hz}, 1 \mathrm{H}), 7.65(\mathrm{dd}, J=5.9,3.1 \mathrm{~Hz}, 1 \mathrm{H}), 7.60(\mathrm{~d}, J=2.4 \mathrm{~Hz}, 1 \mathrm{H})$, $7.58-7.55(\mathrm{~m}, 2 \mathrm{H}), 7.54-7.50(\mathrm{~m}, 1 \mathrm{H}), 7.47(\mathrm{~d}, J=8.0 \mathrm{~Hz}, 2 \mathrm{H}), 6.97(\mathrm{~d}, J=8.9 \mathrm{~Hz}, 1 \mathrm{H})$ $5.21(\mathrm{~d}, J=6.5 \mathrm{~Hz}, 2 \mathrm{H}), 4.31(\mathrm{~s}, 3 \mathrm{H}), 1.76(\mathrm{~s}, 6 \mathrm{H}), 1.36(\mathrm{~s}, 12 \mathrm{H}) .{ }^{13} \mathrm{C} \mathrm{NMR}\left(100 \mathrm{MHz}, \mathrm{CDCl}_{3}\right)$ : $\delta 182.91,158.11,147.32,141.95,138.20,135.57,133.22,130.36,129.99,125.04,122.79$, 
$115.73,115.54,114.86,114.67,84.35,71.61,52.86,37.33,27.23,25.19$. MS (ESI): $\mathrm{m} / \mathrm{z}$ calc. for $\mathrm{C}_{32} \mathrm{H}_{36} \mathrm{BBrNO}_{3}^{+}: 573.35$; found: $574.1[\mathrm{M}]^{+}$

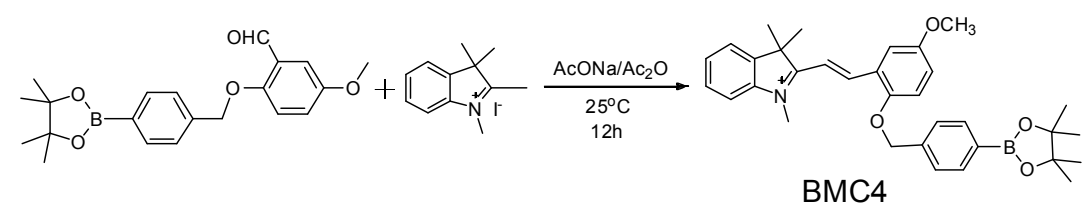

Synthesis of BMC4.A mixture of 5-methoxy-2-((4-(4,4,5,5-tetramethyl-1,3,2dioxaborolan-2-yl)benzyl)oxy)benzaldehyde (0.067 mmol), 1,2,3,3-tetramethyl-3H- indolium iodide $(0.2994 \mathrm{~g}, 0.0994 \mathrm{mmol})$ and sodium acetate $(0.0816 \mathrm{~g}, 0.0994 \mathrm{mmol})$ was reacted in acetic anhydride $(20 \mathrm{~mL})$ according to general procedure to give BMC4 $(90 \%)$ as a dark brown solid. ${ }^{1} \mathrm{H}$ NMR(400MHz, $\left.\mathrm{CDCl}_{3}\right): \delta 8.69(\mathrm{~d}, J=16.4 \mathrm{~Hz}, 1 \mathrm{H}), 7.90-7.85(\mathrm{~m}, 3 \mathrm{H})$, $7.84(\mathrm{~d}, J=2.9 \mathrm{~Hz}, 1 \mathrm{H}), 7.57(\mathrm{~d}, J=1.4 \mathrm{~Hz}, 2 \mathrm{H}), 7.56-7.53(\mathrm{~m}, 2 \mathrm{H}), 7.51(\mathrm{~d}, J=4.6 \mathrm{~Hz}$, 1H), $7.47(\mathrm{~d}, J=8.0 \mathrm{~Hz}, 2 \mathrm{H}), 7.00(\mathrm{~d}, J=9.2 \mathrm{~Hz}, 1 \mathrm{H}), 5.18(\mathrm{~s}, 2 \mathrm{H}), 4.39$ (s, 3H), $4.06(\mathrm{~s}, 3 \mathrm{H})$, $1.73(\mathrm{~s}, 6 \mathrm{H}), 1.37(\mathrm{~s}, 12 \mathrm{H}) .{ }^{13} \mathrm{C} \mathrm{NMR}\left(100 \mathrm{MHz}, \mathrm{CDCl}_{3}\right): \delta 183.07,155.01,154.31,149.88$, $143.25,141.78,139.36,135.51,129.99,127.09,125.24,123.80,122.78,122.58,114.86$, $114.47,113.17,112.84,84.34,71.76,58.23,52.61,37.51,27.40,25.19$. MS (ESI): $\mathrm{m} / \mathrm{z}$ calc. for $\mathrm{C}_{33} \mathrm{H}_{39} \mathrm{BNO}_{4}^{+}:$524.48; found: $524.2[\mathrm{M}]^{+}$

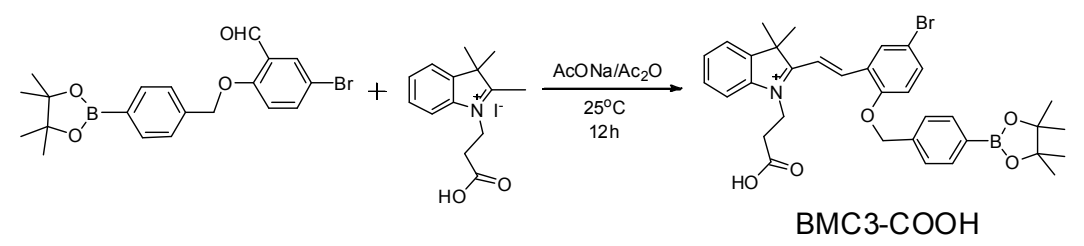

Synthesis of BMC3-COOH. ${ }^{1} \mathrm{H} \mathrm{NMR}\left(400 \mathrm{MHz}, \mathrm{CDCl}_{3}\right): \delta 8.45(\mathrm{~d}, J=16.5 \mathrm{~Hz}, 1 \mathrm{H}), 8.33$ $(\mathrm{d}, J=2.4 \mathrm{~Hz}, 1 \mathrm{H}), 7.87(\mathrm{~d}, J=8.1, \mathrm{~Hz}, 2 \mathrm{H}), 7.73(\mathrm{~d}, J=16.5 \mathrm{~Hz}, 1 \mathrm{H}), 7.65(\mathrm{dd}, J=5.9,3.1$ $\mathrm{Hz}, 1 \mathrm{H}), 7.58-7.55(\mathrm{~m}, 2 \mathrm{H}), 7.54-7.50(\mathrm{~m}, 1 \mathrm{H}), 7.47$ (d, $J=8.0 \mathrm{~Hz}, 2 \mathrm{H}), 6.97(\mathrm{~d}, J=8.9$ 
$\mathrm{Hz}, 1 \mathrm{H}), 5.21(\mathrm{~d}, J=6.5 \mathrm{~Hz}, 1 \mathrm{H}), 4.31(\mathrm{~s}, 2 \mathrm{H}), 3.72(\mathrm{t}, J=6.7 \mathrm{~Hz}, 2 \mathrm{H}), 3.14(\mathrm{t}, J=6.7 \mathrm{~Hz}$, 2H), $1.76(\mathrm{~s}, 6 \mathrm{H}), 1.36(\mathrm{~s}, 12 \mathrm{H}) .{ }^{13} \mathrm{C} \mathrm{NMR}\left(100 \mathrm{MHz}, \mathrm{CDCl}_{3}\right) \delta 182.91,176.62,158.11$, $147.32,143.31,141.85,138.67,138.20,135.57,133.22,130.36,129.99,127.16,125.04$, $122.79,115.54,114.89,114.67,84.35,71.61,52.86,37.54,37.33,27.23,25.19,24.96 . \mathrm{MS}$ (ESI): $\mathrm{m} / \mathrm{z}$ calc. for $\mathrm{C}_{34} \mathrm{H}_{38} \mathrm{BBrNO}_{5}{ }^{+}: 631.38$; found: $630.2[\mathrm{M}]^{+}$

\section{${ }^{1}$ H NMR ${ }^{13}$ C NMR and HRMS (ESI)}

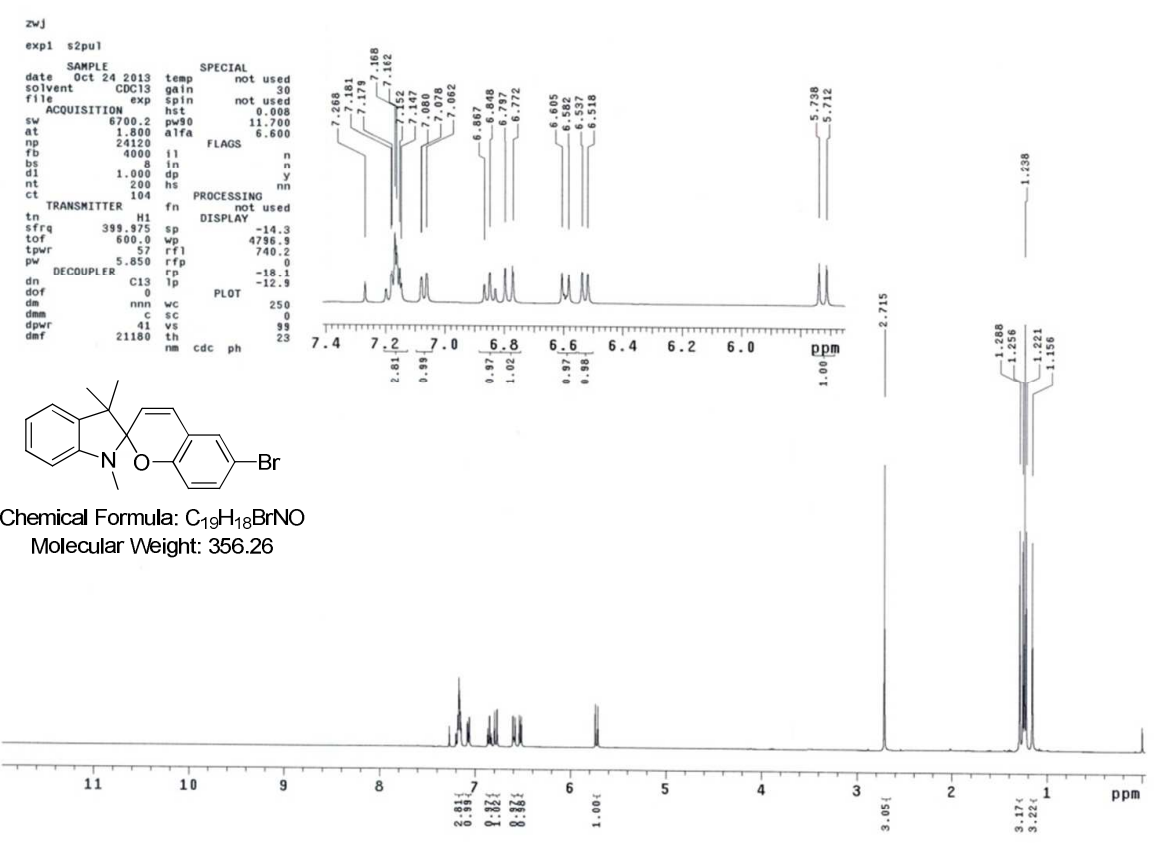




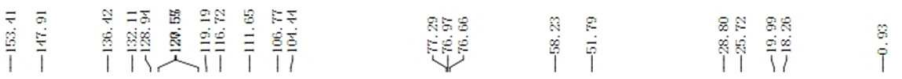

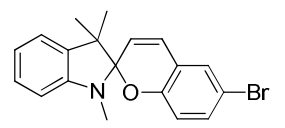

Chemical Formula: $\mathrm{C}_{19} \mathrm{H}_{18} \mathrm{BrNO}$

Molecular Weight: 356.26

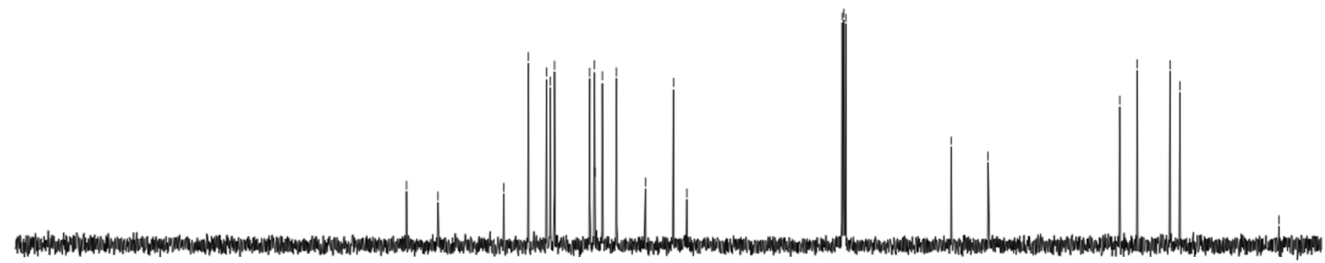

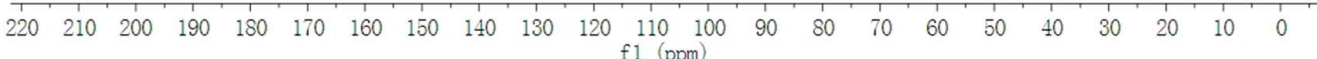

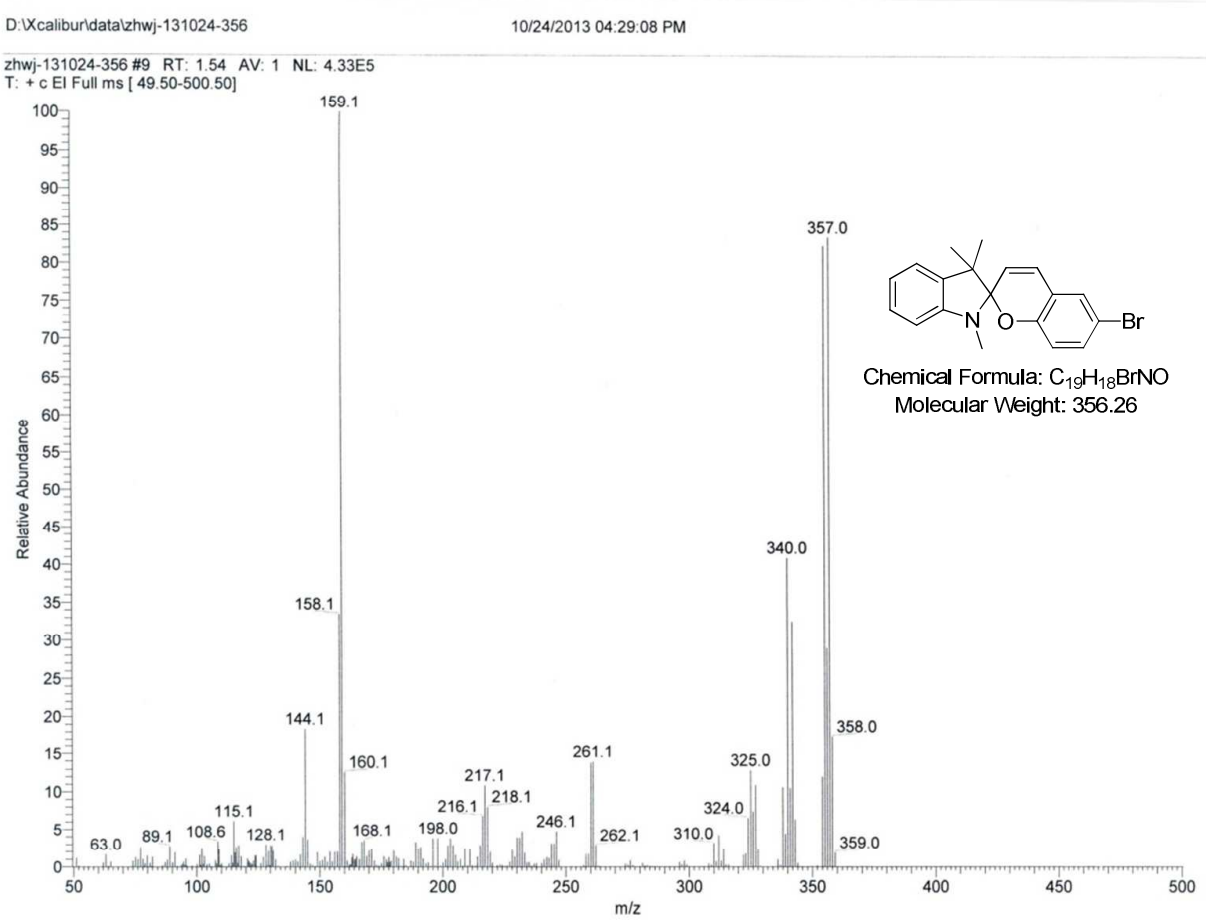



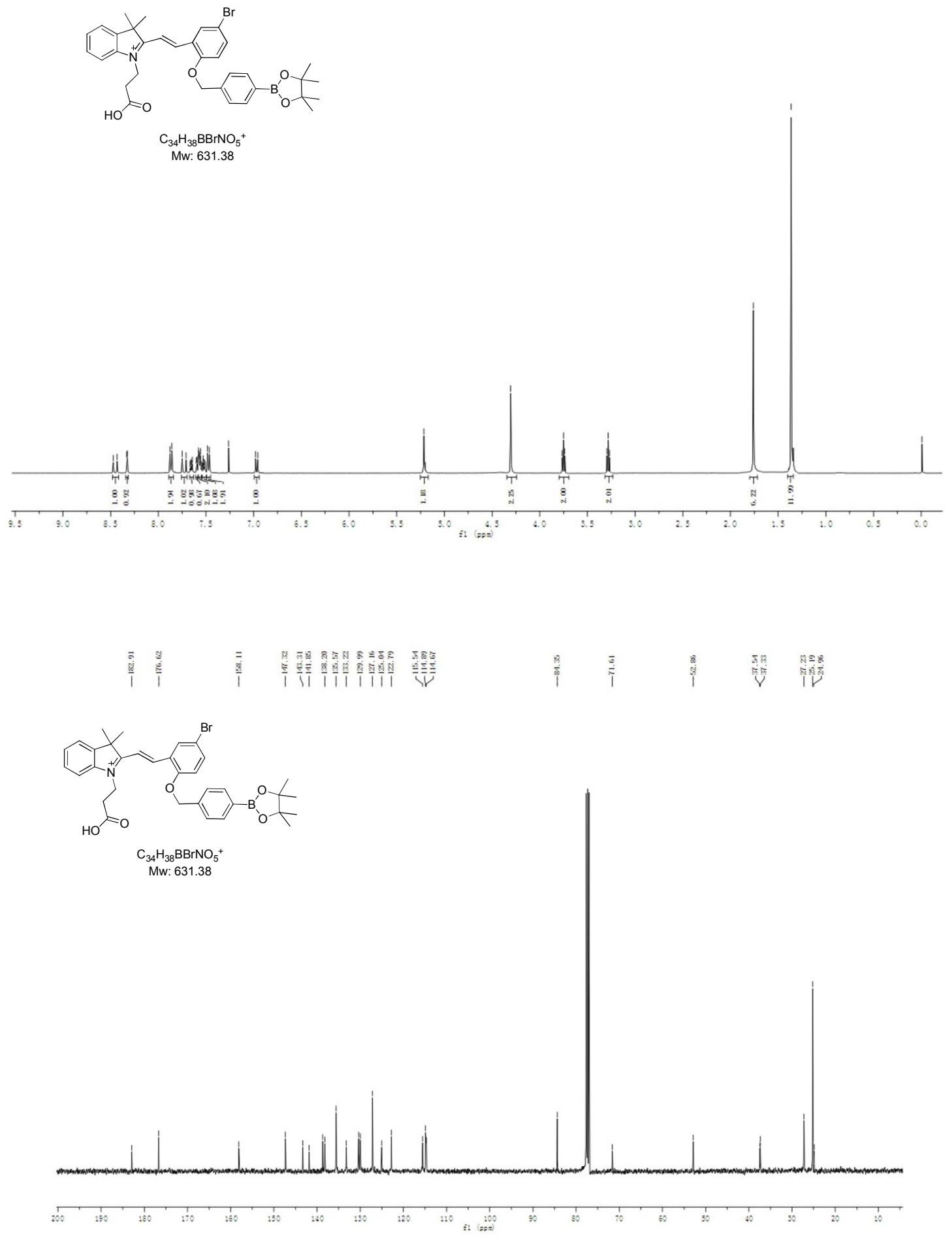


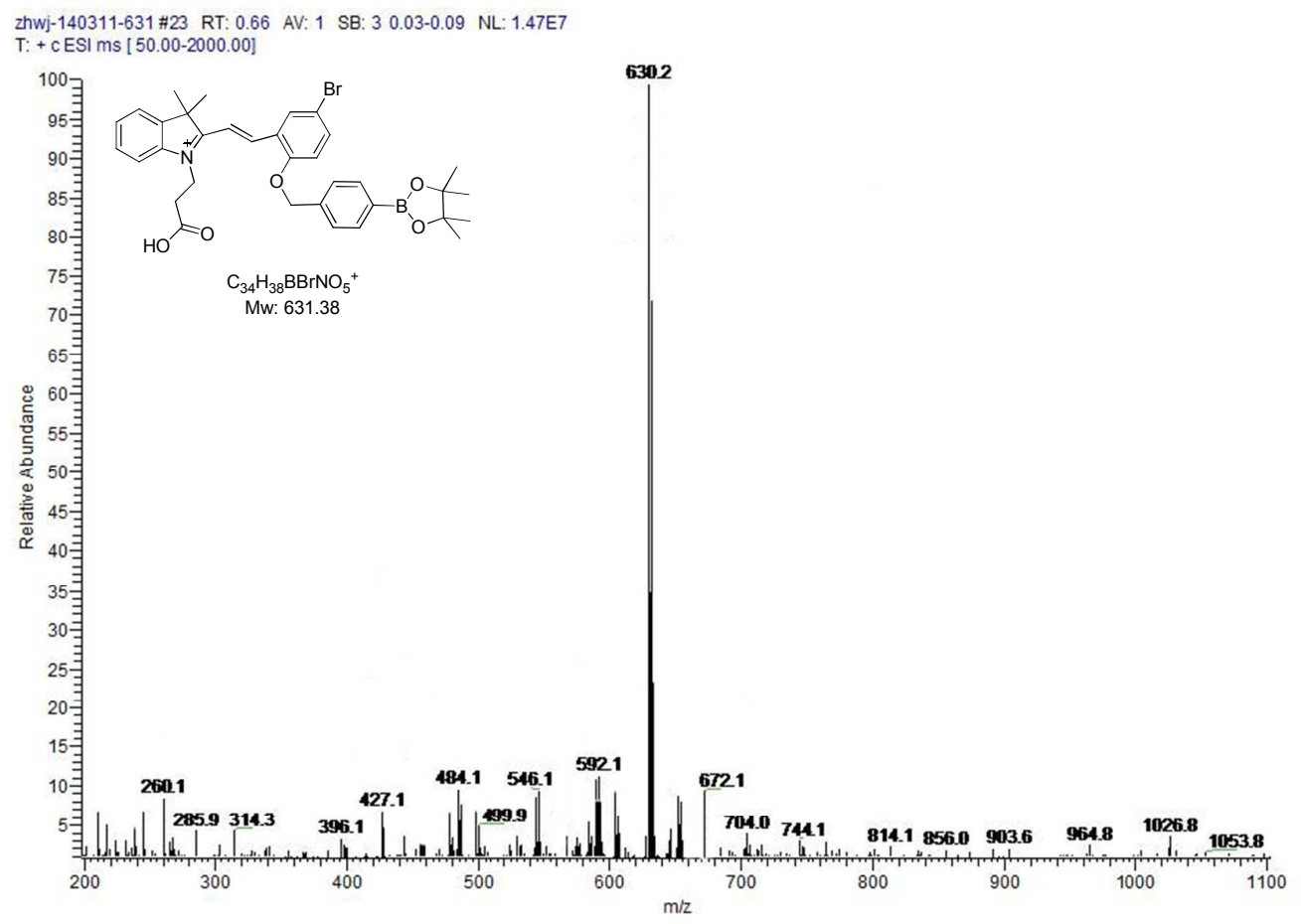

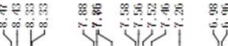

ูํำ

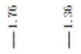

i

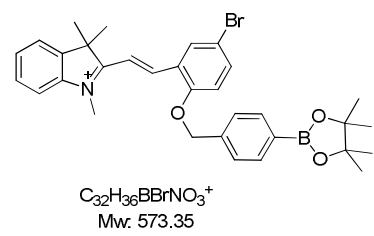

Mw. 573.35

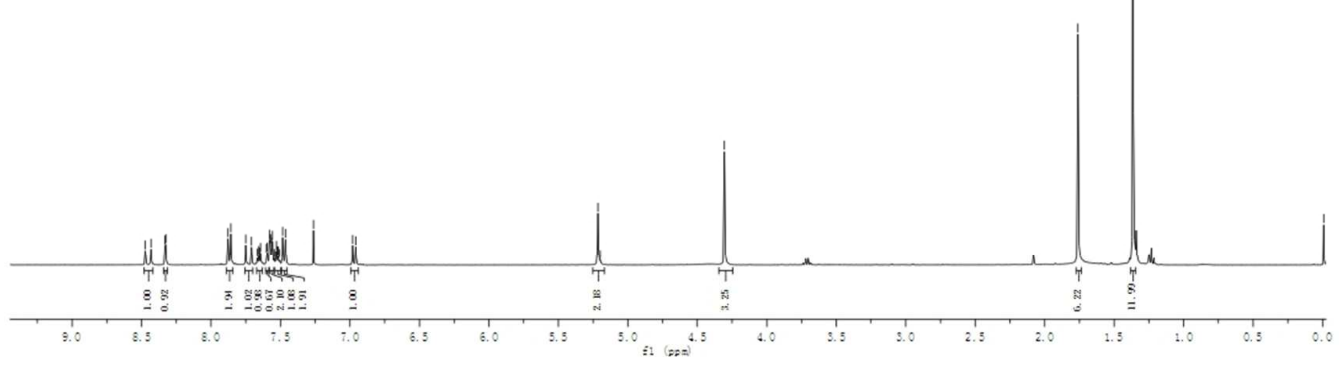



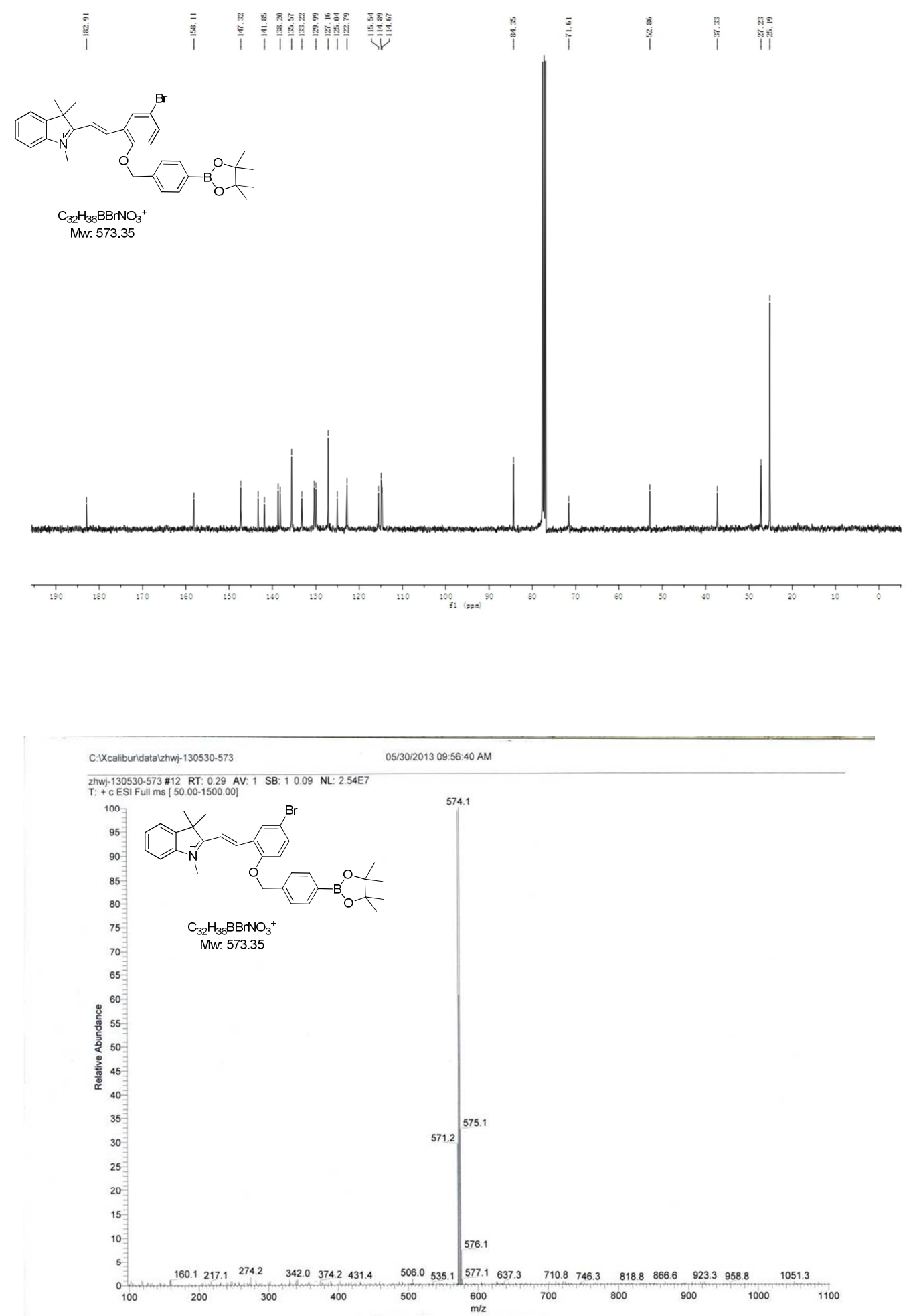

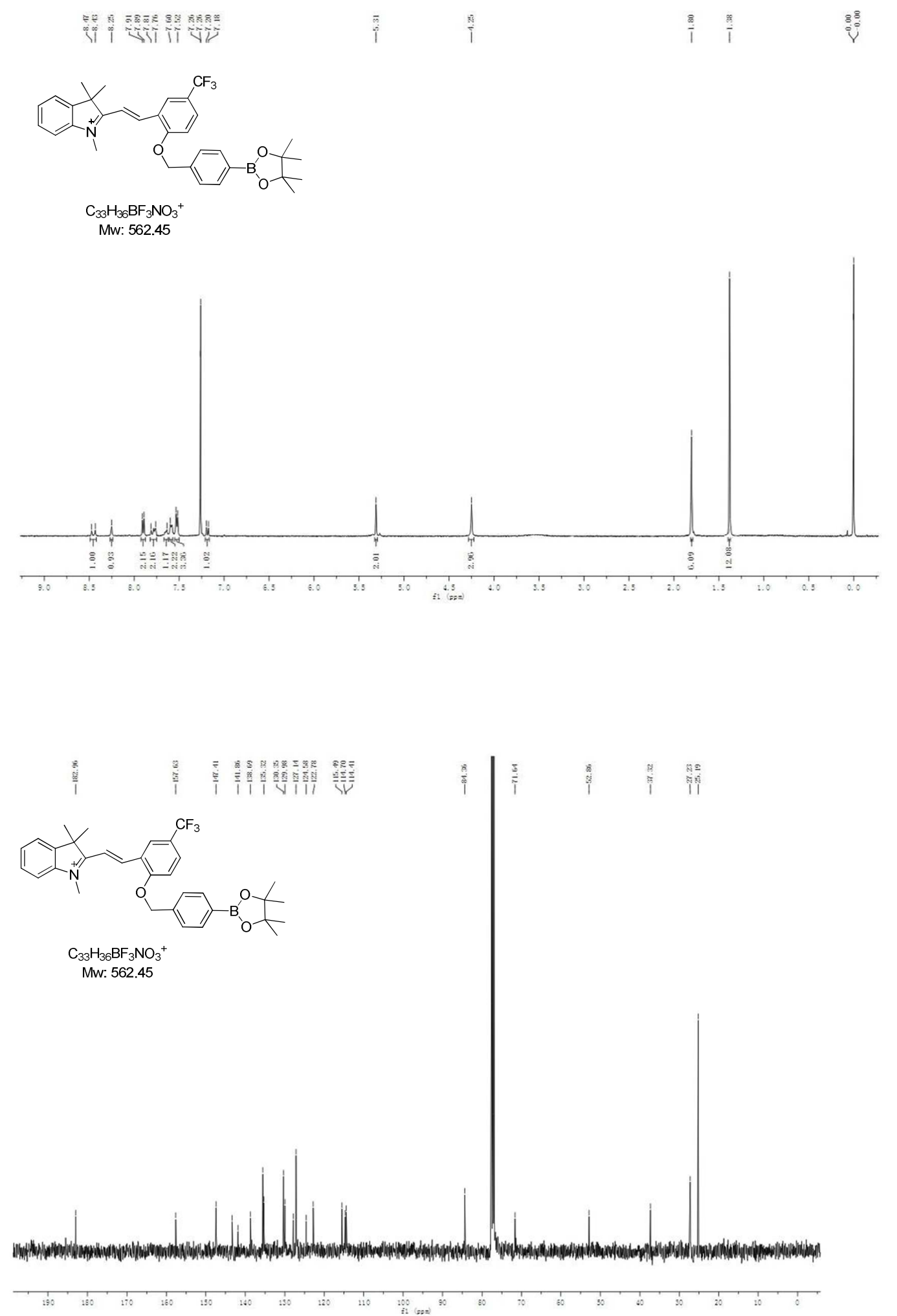


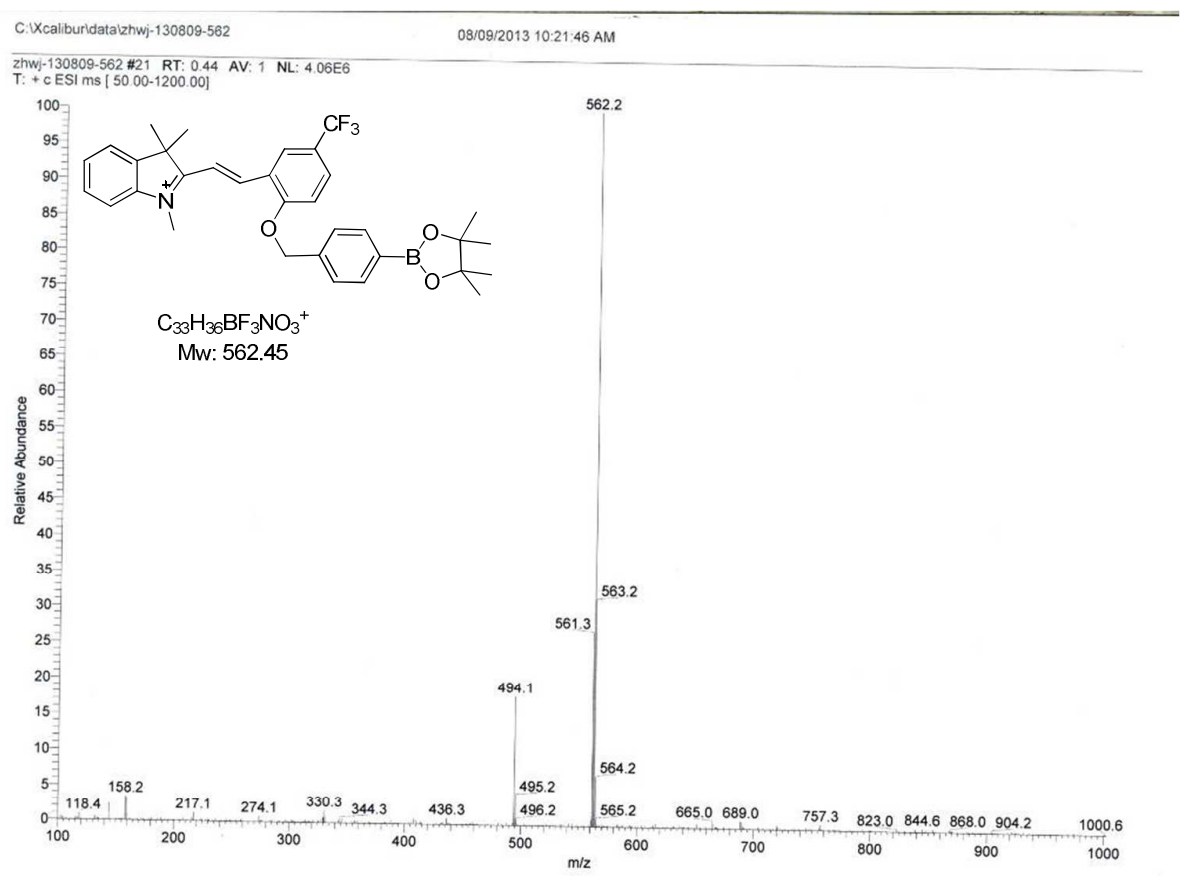

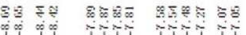

i

$\stackrel{2}{1}$

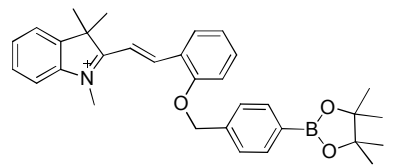

$\mathrm{C}_{32} \mathrm{H}_{37} \mathrm{BNO}_{3}{ }^{+}$

Mw: 494.45

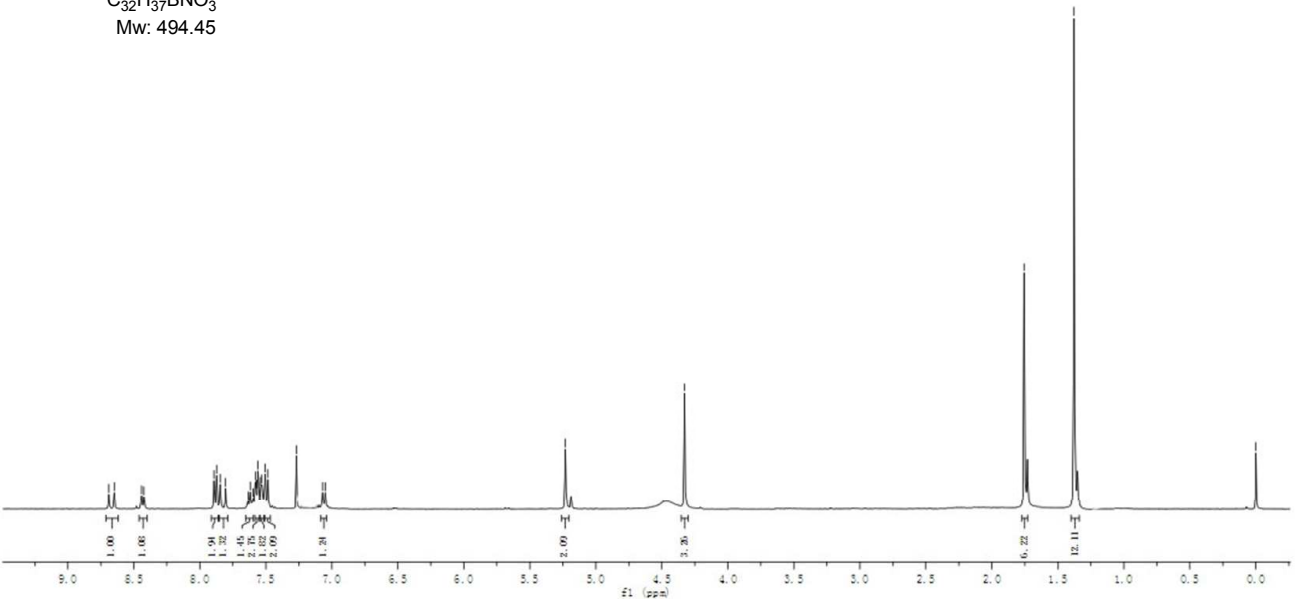



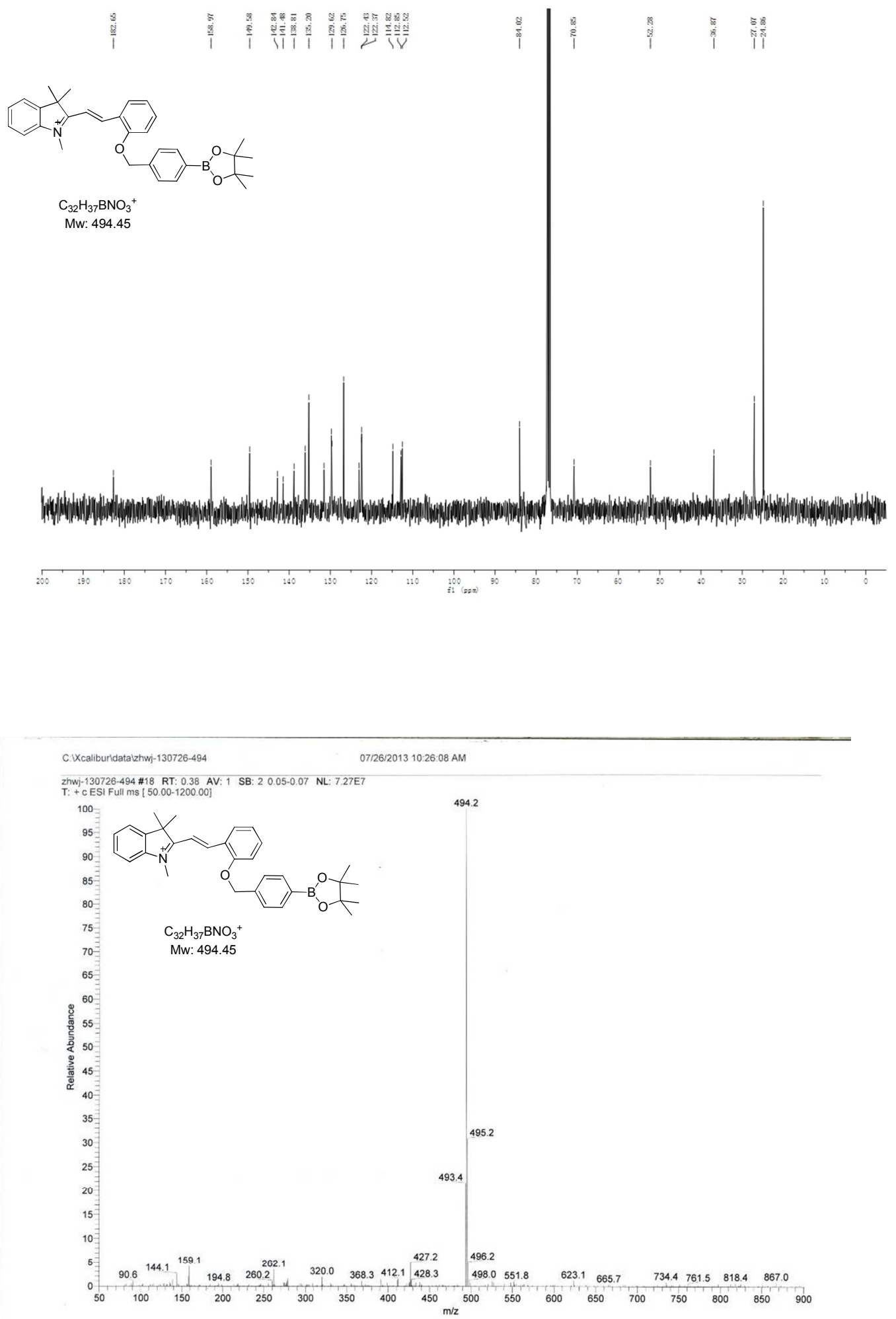

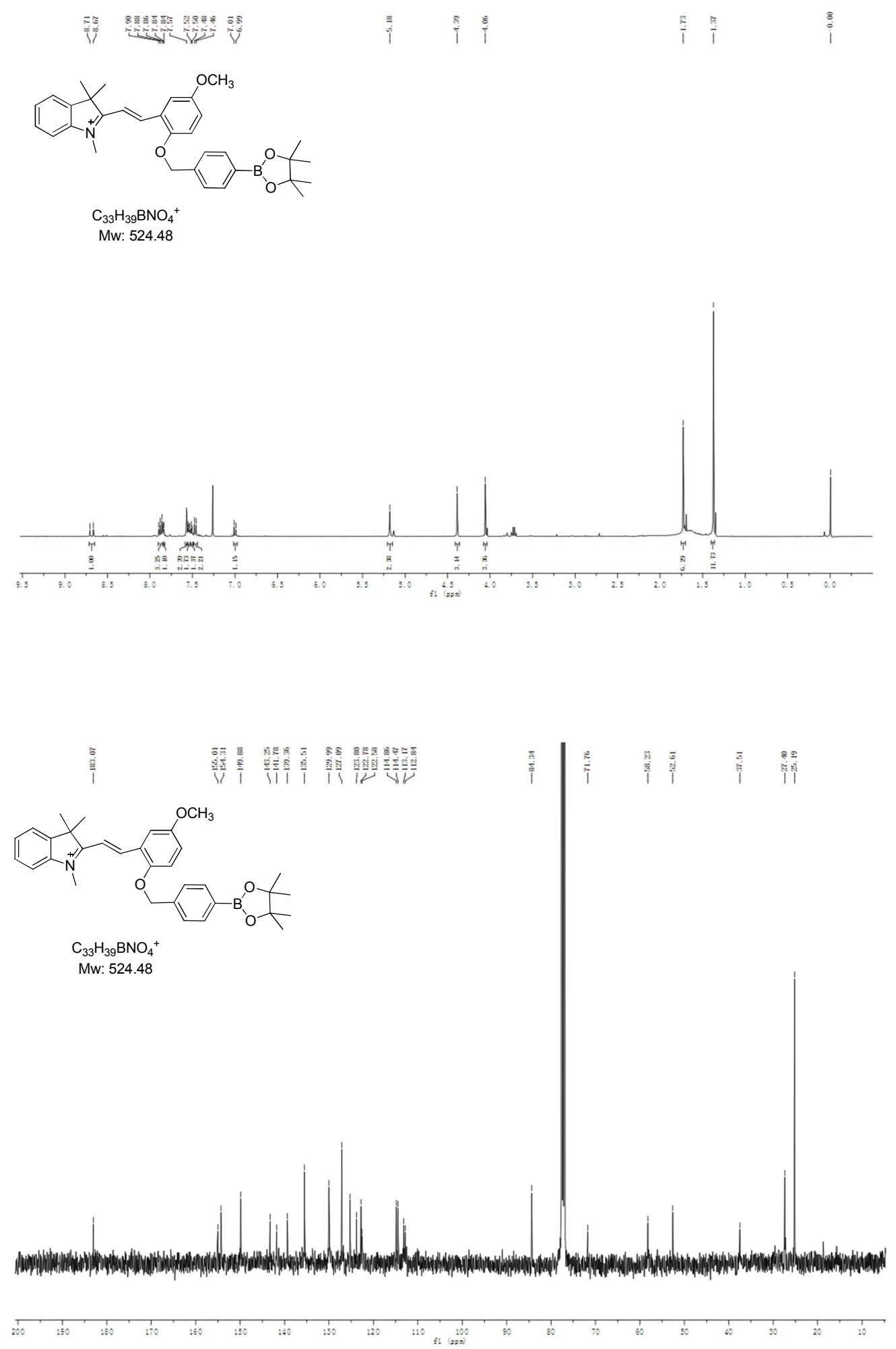


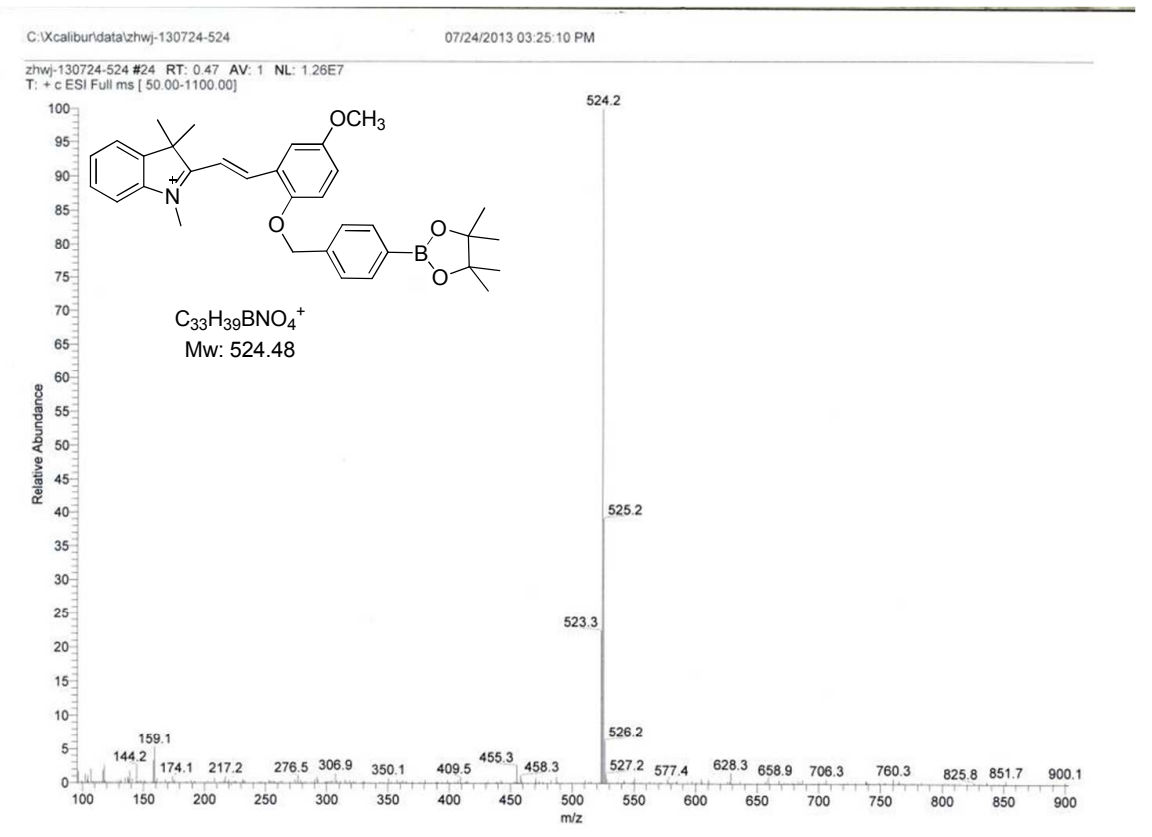

zhwj-140415-466 \#28 RT: 0.53 AV: 1 NL: 4.53E6

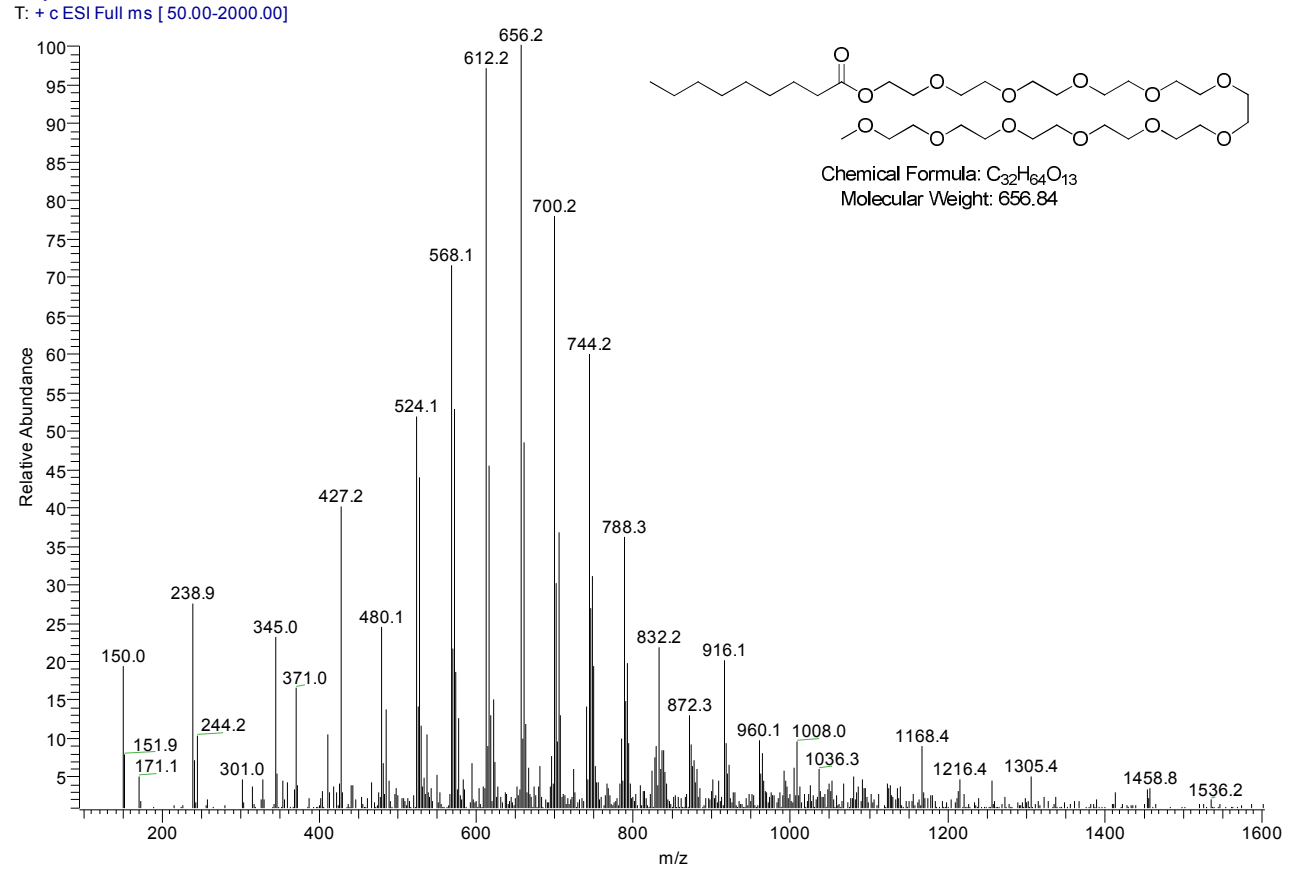

